Boise State University

ScholarWorks

Geosciences Faculty Publications and

Presentations

Department of Geosciences

$5-2015$

\title{
Westward Growth of Laurentia by Pre-Late Jurassic Terrane Accretion, Eastern Oregon and Western Idaho, United States
}

\author{
Todd A. LaMaskin \\ University of North Carolina Wilmington \\ Rebecca J. Dorsey \\ University of Oregon \\ Jeffrey D. Vervoort \\ Washington State University \\ Mark D. Schmitz \\ Boise State University \\ Kyle P. Tumpane \\ Boise State University
}

See next page for additional authors

This document was originally published by The University of Chicago Press in The Journal of Geology. Copyright restrictions may apply. doi: 10.1086/681724 


\section{Authors}

Todd A. LaMaskin, Rebecca J. Dorsey, Jeffrey D. Vervoort, Mark D. Schmitz, Kyle P. Tumpane, and Nicholas O. Moore 


\title{
Westward Growth of Laurentia by Pre-Late Jurassic Terrane Accretion, Eastern Oregon and Western Idaho, United States
}

\author{
Todd A. LaMaskin, ${ }^{1, \star}$ Rebecca I. Dorsey, ${ }^{2}$ Ieffrey D. Vervoort, ${ }^{3}$ Mark D. Schmitz, ${ }^{4}$ \\ Kyle P. Tumpane, ${ }^{4}$ and Nicholas O. Moore ${ }^{1}$ \\ 1. Department of Geography and Geology, University of North Carolina Wilmington, 601 South College Road, \\ Wilmington, North Carolina 28403-5944, USA; 2. Department of Geological Sciences, University of Oregon, \\ 1272 University of Oregon, Eugene, Oregon 97403-1272, USA; 3. School of the Environment, Washington \\ State University, Pullman, Washington 99164-2812, USA; 4. Department of Geosciences, Boise \\ State University, 1910 University Drive, Boise, Idaho 83725-1535, USA
}

\begin{abstract}
A B S T R A C T
New U-Pb and Sm-Nd data from the Blue Mountains province, eastern Oregon and western Idaho, clarify terrane correlations and regional evolution of the western Laurentian plate margin during Mesozoic time. We report an Early Jurassic age for a red tuff unit at Pittsburg Landing, Idaho, which is $25 \mathrm{~m}$.yr. older than previous Middle Jurassic estimates. In the Coon Hollow Formation at Pittsburg Landing and at the type location on the Snake River, chemical abrasion thermal ionization mass spectrometry $\mathrm{U}-\mathrm{Pb}$ zircon ages on interbedded tuff and detrital zircon $\mathrm{U}-\mathrm{Pb}$ maximum depositional ages indicate that deposition spanned ca. 160-150 Ma, entirely during Late Jurassic time. Detrital zircon U-Pb ages represent local Wallowa arc basement and regional magmatic sources spanning ca. 290-140 Ma. Mudrock Nd isotope compositions of the Coon Hollow Formation record an increase in juvenile magmatism consistent with regional Late Jurassic trends in western North American magmatic systems. These data show that the Coon Hollow Formation is not part of a Middle Jurassic overlap assemblage, as has been historically interpreted. Instead, we propose that the Coon Hollow Formation is part of a belt of suprasubduction-zone extensional back-arc basins that formed in latest Jurassic time due to a well-documented period of trench retreat in the western United States. Our new data require that the underlying Wallowa terrane was accreted to and received detritus from western North America by ca. $160 \mathrm{Ma}$ (early Late Jurassic). This minimum estimate for the age of terrane accretion in western Idaho and eastern Oregon is substantially earlier than previous estimates ( 135-118 Ma). In the Blue Mountains region, westward expansion of Laurentia was accomplished by accretion of arc terranes to the North American craton prior to Late Jurassic time.
\end{abstract}

Online enhancement: supplementary data.

\section{Introduction}

Late Paleozoic to early Mesozoic terranes in the western United States (fig. 1) record westward expansion of continental crust by accretion of volcanic arc lithosphere. While authors agree that accretion of these late Paleozoic to early Mesozoic terranes records Mesozoic westward expansion of the Laurentian margin, significant controversies remain unresolved, including the origin of these terranes as either far-traveled or fringing-arc successions and the timing of their accretion to western North America

Manuscript received January 9, 2014; accepted March 19, 2015; electronically published May 29, 2015.

* Author for correspondence; e-mail: lamaskint@uncw.edu. as either before or after Late Jurassic time (e.g., Davis et al. 1978; Harper and Wright 1984; Wright and Fahan 1988; Oldow et al. 1989; McLelland et al. 1992; Hacker et al. 1995; Moores et al. 2002; Dorsey and LaMaskin 2007, 2008; Dickinson 2008; Ernst et al. 2008; Hildebrand 2009, 2013; Schwartz et al. 2010, 2011a, 2011b, 2014; LaMaskin 2012; Sigloch and Mihalynuk 2013).

After decades of research in the accreted terranes of the Blue Mountains province (BMP) of eastern Oregon and western Idaho (figs. 1, 2), two contrasting end-member tectonic models for the Jurassic tectonic setting and evolution have emerged (fig. 3). The first model (fig. $3 A$ ) proposes Early-Middle Ju-

[The Journal of Geology, 2015, volume 123, p. 233-267] (C) 2015 by The University of Chicago. All rights reserved. 0022-1376/2015/12303-0002\$15.00. DOI:10.1086/681724 


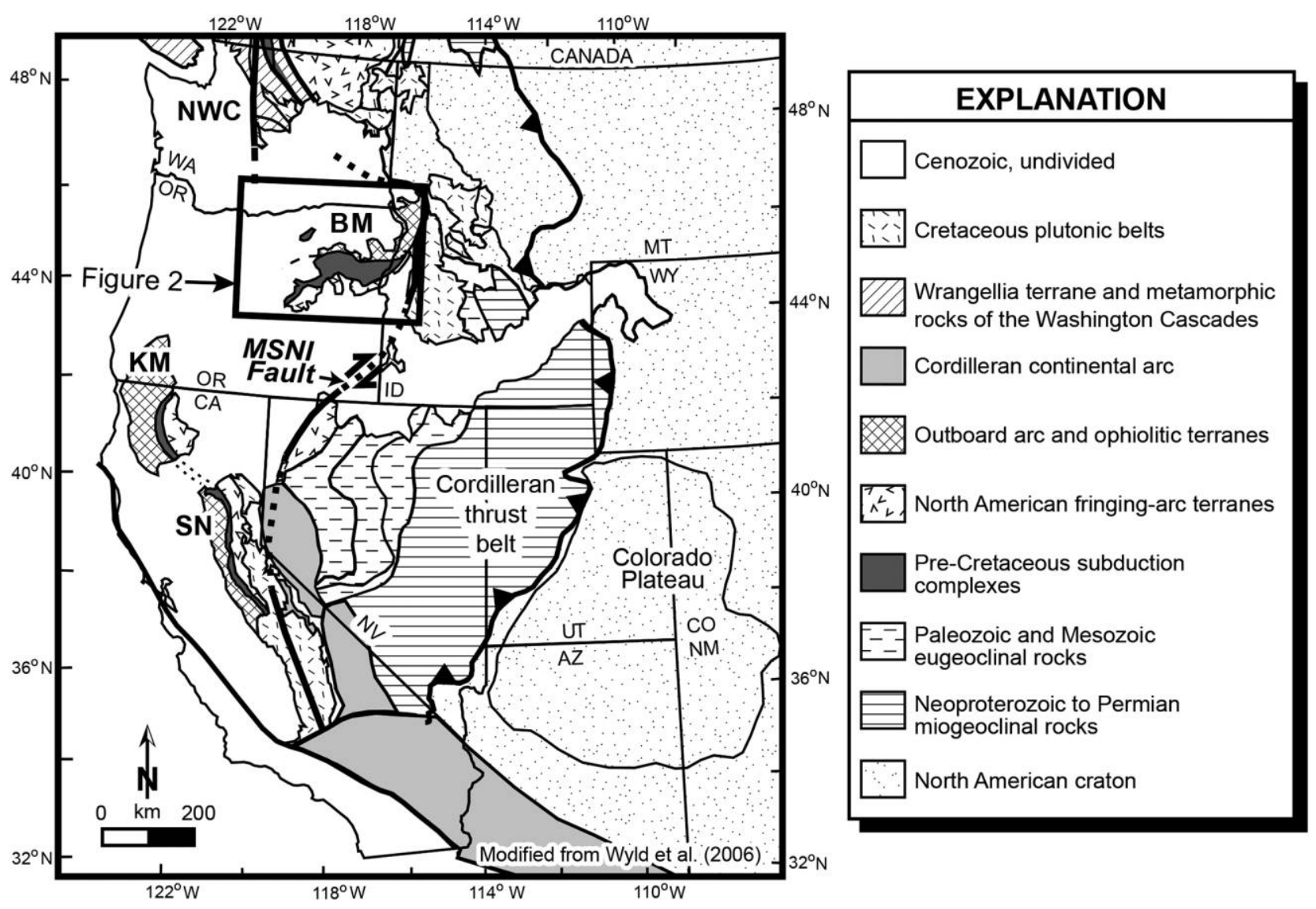

Figure 1. Simplified pre-Tertiary geology of the western United States, modified from Wyld et al. (2006). BM = Blue Mountains province; KM = Klamath Mountains; MSNI = Mojave-Snow Lake-Nevada-Idaho fault (after Wyld and Wright 2005); NWC = northwestern Cascades; SN = Sierra Nevada.

rassic noncollisional double subduction, followed by Late Jurassic offshore arc-arc collision (Dickinson 1979, 2004; Avé Lallemant 1995; Schwartz et al. 2010, 2011a, 2011b, 2012). We use the term "collision" specifically for convergent plate interactions in which buoyant crust is drawn into a trench zone, effectively jamming subduction, which leads to crustal shortening, thickening, metamorphism, and uplift (sensu Cloos 1993; Dorsey and LaMaskin 2007; Dickinson 2008). A second model (fig. 3B) proposes Early-Middle Jurassic accretion of the previously collided BMP terranes to the western North American margin by closure of a marginal basin, followed by postaccretion outboard subduction in the BMP (e.g., Dorsey and LaMaskin 2007, 2008; LaMaskin et al. 2008, 2011a, 2011b; LaMaskin 2012).

In this article, we present new U-Pb geochronology and mudrock $\mathrm{Nd}$ isotope compositions from Early and Late Jurassic rocks of the BMP (figs. 1, 2, 4). These data place important new constraints on the timing and style of Mesozoic terrane evolution and accretion in this region with implications for the dynamic early Mesozoic tectonic setting of western North America. We show that early Mesozoic westward growth of Laurentia occurred by tectonic accretion of previously amalgamated arc terranes prior to $160 \mathrm{Ma}$, significantly earlier than proposed in previous models for the Blue Mountains. Our new data also permit direct correlation to other terranes and basin-fill successions of similar age along the western US Cordillera and provide new insight into the tectonic evolution of subduction plate margins.

\section{Geologic Setting}

BMP Terranes. The accreted terranes of the BMP (figs. 1,2) include island arcs and arc-related basins that formed in proximity to the North American craton (Olds Ferry, Izee, and Baker terranes) and offshore from North America (Wallowa terrane). The Olds Ferry and Izee terranes are the most inboard (farthest east in restored coordinates) of the 


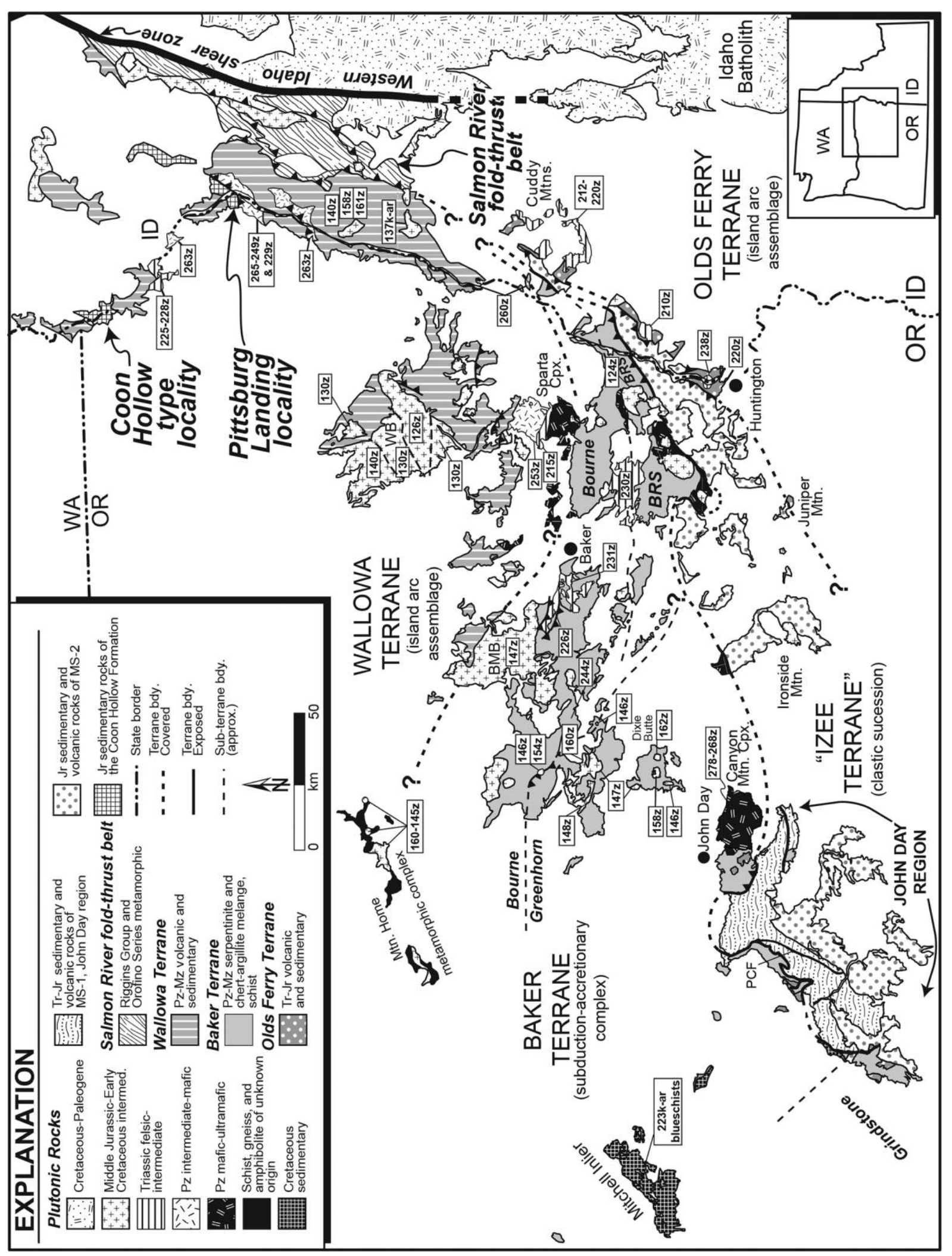

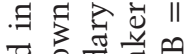

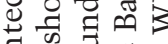

串记苛

党, 嵌

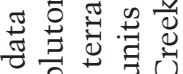

范岩宁

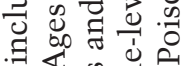

요

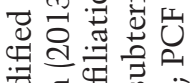

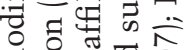

घ.

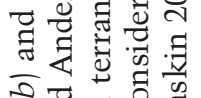

青完

宁完五总

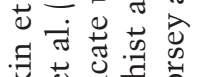

吾

$\sum_{\pi}^{\infty}, N$ 光

西学密

쿰ㅁㅇㅛ

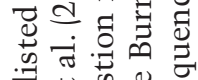

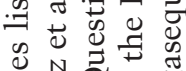

입.

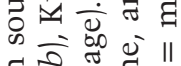

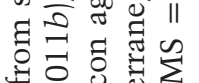

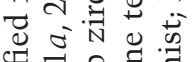

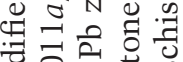

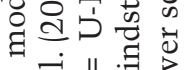

जक 11 青

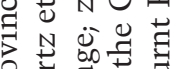

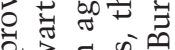

2. 3 舟

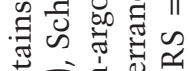

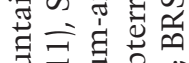

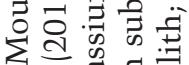

品

에 110

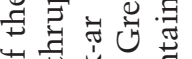

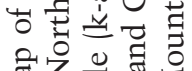

घี

이유.

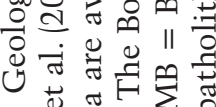

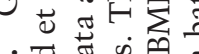

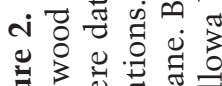

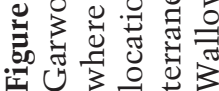



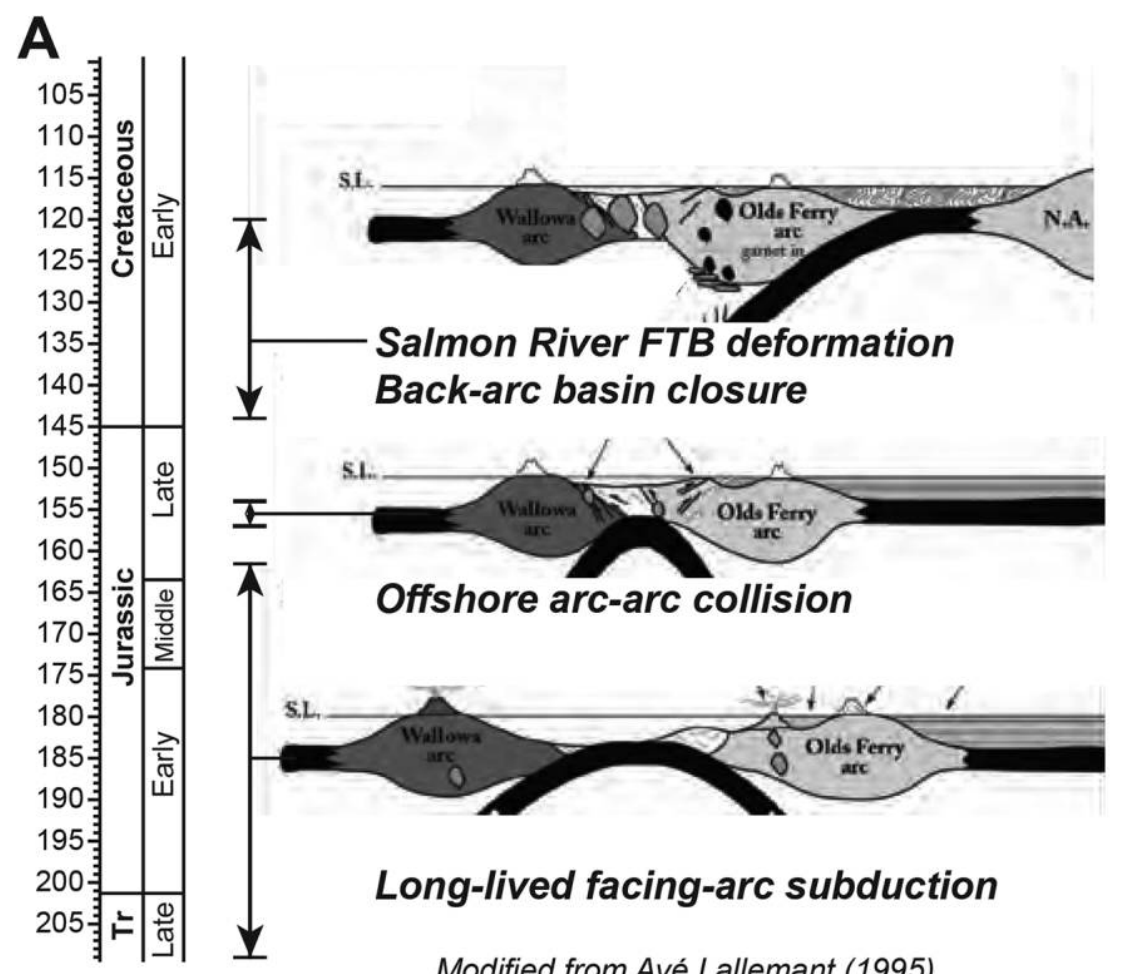

\section{Long-lived facing-arc subduction}

Modified from Avé Lallemant (1995),

Schwartz et al. (2011a, b; 2012)

\section{B}

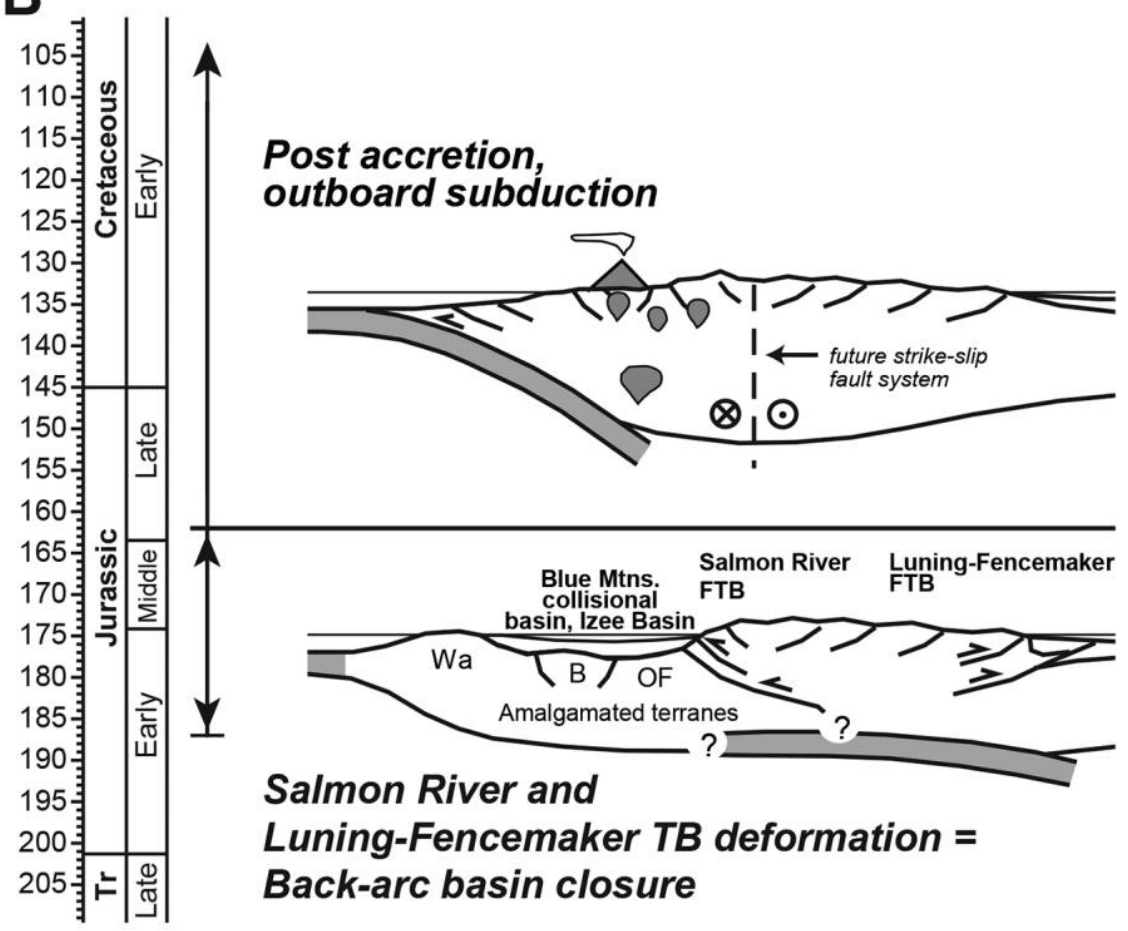

Modified from Dorsey and LaMaskin (2007)

Figure 3. Models for Jurassic tectonic setting and evolution of the Blue Mountains province (BMP). A, Early-Middle Jurassic noncollisional double subduction, followed by Late Jurassic offshore arc-arc collision (Dickinson 1979, 2004; Avé Lallemant 1995; Schwartz et al. 2010, 2011a, 2011b, 2012). B, Early-Middle Jurassic accretion of the previously collided BMP terranes to the western North American margin by closure of a marginal basin, followed by postaccretion outboard subduction in the BMP (e.g., Dorsey and LaMaskin 2007, 2008; LaMaskin et al. 2008a, 2011a, 2011b; LaMaskin 2012). B = Baker terrane; FTB $=$ fold-thrust belt; N.A. = North America $;$ OF $=$ Olds Ferry terrane; S.L. $=$ sea level; $\mathrm{TB}=$ thrust belt; $\mathrm{Wa}=$ Wallowa terrane. 


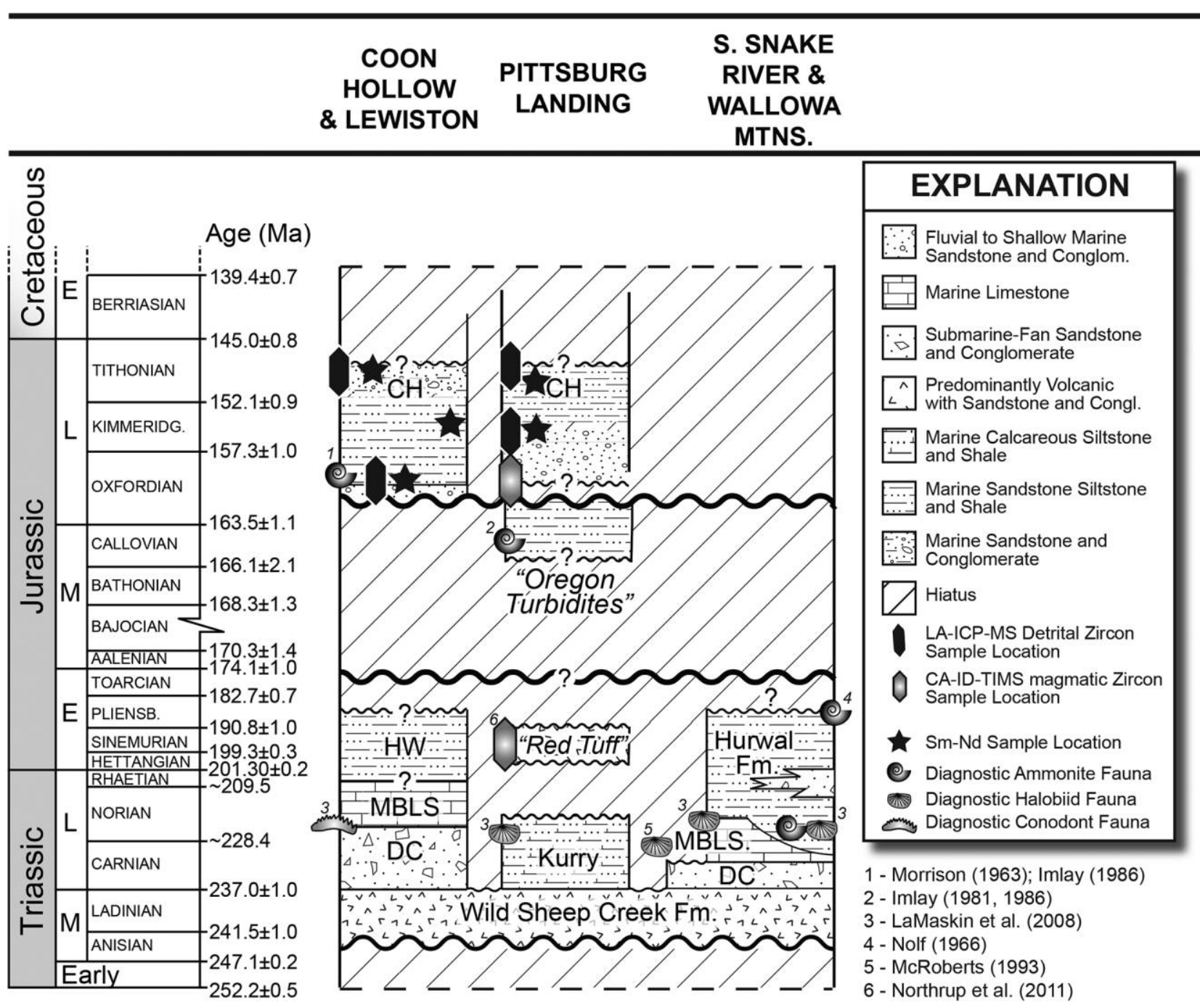

Figure 4. Sample locations plotted on a chronostratigraphic correlation chart for sedimentary and volcanic rocks in the Blue Mountains. Modified from Dorsey and LaMaskin (2007). See Dorsey and LaMaskin (2007) for additional data sources. Note that formation time ranges are plotted according to new data presented in this article. CA-ID-TIMS $=$ chemical abrasion isotope dilution thermal ionization mass spectrometry; $\mathrm{CH}=$ Coon Hollow Formation; $\mathrm{DC}=$ Doyle Creek Formation; HW = Hurwal Formation; LA-ICP-MS = laser ablation inductively coupled plasma mass spectrometry; MBLS = Martin Bridge limestone.

BMP terranes and contain Permian?-Jurassic plutonic, volcanic, and volcaniclastic sedimentary rocks (figs. 2, 4). In the Olds Ferry-Izee succession, Late Triassic sedimentary rocks contain abundant ArcheanPaleozoic detrital zircon grains derived from recycled late Paleozoic arcs, whereas Jurassic deposits contain abundant Proterozoic-Mesozoic grains sourced from continental rocks to the east (LaMaskin et al. $2011 b$ ). Enriched sedimentary trace element compositions and pre-Mesozoic detrital zircon U-Pb ages indicate that Olds Ferry-Izee Jurassic-age arc-related basins received continentally sourced sediment, supporting the interpretation that they represent a continent-fringing volcanic arc system (LaMaskin et al. 2008a, 2011b; Tumpane 2010; Kurz 2010; Northrup et al. 2011).

The Baker terrane subduction-accretionary complex separates the Wallowa and Olds Ferry-Izee terranes and represents deformed Olds Ferry-Izee forearc crust and the associated accretionary prism (fig. 2; Brooks 1979; Dickinson 1979; Ferns and Brooks 1995; Schwartz et al. 2010). Rocks of the Baker terrane display both juvenile and evolved isotopic compositions (Schwartz et al. 2010) and contain Archean and Proterozoic detrital zircon grains (Alexander and Schwartz 2009). The Baker terrane is 
widely considered to be correlative to similar rocks of the Cache Creek terrane in British Columbia (e.g., Kays et al. 2006; Wyld et al. 2006).

The Wallowa terrane includes Permian-Early Jurassic arc-related rocks and occupies an outboard (oceanward) position relative to other terranes in the BMP (fig. 2). Permian-Triassic rocks of the Wallowa terrane show relatively flat rare earth element patterns and negligible Eu anomalies, suggesting that during most of the Triassic time the Wallowa terrane did not receive sediment from continental sources and likely represents a juvenile, intraoceanic volcanic arc (LaMaskin et al. 2008a, 2008b; Kurz 2010). Wallowa arc basement includes Permian-Lower Triassic plutonic rocks (ca. 265-249 Ma) and Late Triassic rocks (ca. 229 and 215 Ma; Walker 1995; Kurz et al. 2011). Volcanic cover rocks of the Wild Sheep Creek and Doyle Creek Formations are Late Triassic in age (ca. 230 Ma; Vallier 1995; LaMaskin et al. 2008b; Kurz et al. 2011). At isolated localities along the Oregon-Idaho border and in far western Idaho, Wallowa terrane rocks are depositionally overlain along an angular unconformity by fluvial to deep-marine sedimentary rocks of the Coon Hollow Formation (CHF; figs. 2, 4, 5A, 6; Morrison 1963; Vallier 1977, 1995; Goldstrand 1994; LaMaskin et al. 2008a; Kauffman et al. 2009; Schmidt et al. 2009). The CHF has traditionally been considered the uppermost unit of the Wallowa terrane and therefore is commonly believed to be allochthonous relative to North America (Vallier 1977, 1995).

BMP terranes may have been affected by unknown amounts of dextral-transpressive displacements during Mesozoic time, as inferred from regional paleomagnetic inclinations, geologic correlations, and kinematic fabrics preserved in regional plutonic rocks, calling into question their original paleolatitude (e.g., Wyld and Wright 2001; Housen and Dorsey 2005; Wyld et al. 2006). Different tectonic reconstructions have relied on different amounts of displacement: (1) $<100 \mathrm{~km}$ of displacement (e.g., Dickinson 2004, 2006; Gray and Oldow 2005) implies that during preCretaceous time the BMP was outboard of an enigmatic Pacific Northwest continental margin and that the history of this margin has been subsequently obscured by pluton emplacement and Cretaceous shortening; (2) $\sim 400 \mathrm{~km}$ of displacement juxtaposes the Triassic-Jurassic western US fringing arc complex of the BMP (Olds Ferry terrane) with island arc and back-arc basin rocks of northern Nevada (Black Rock terrane and Auld Lang Syne Group in western Nevada; e.g., Oldow 1984; Wyld and Wright 2001; Wyld 2002; Wyld et al. 2003, 2006; LaMaskin et al. 2011a); and (3)>1000 km of displacement (e.g., Housen and Dorsey 2005, after $94 \mathrm{Ma}$ ) places the BMP at the approximate latitude of southwestern Arizona and northern Mexico adjacent to the Jurassic continental arc (Saleeby and BusbySpera 1992; Dickinson and Lawton 2001).

Salmon River Fold-Thrust Belt and Western Idaho Shear Zone. In western Idaho, the Wallowa terrane is structurally overridden by the Salmon River foldthrust belt, and the inboard Baker, Izee, and Olds Ferry terranes of the BMP appear to be absent because of regional tectonic truncation (fig. 2). The Salmon River belt is a zone of strong crustal shortening and thickening that consists of greenschist to amphibolite facies rocks exposed in a belt of topto-the-west thrust nappes where the metamorphic grade increases eastward to higher structural levels (fig. 2; e.g., Lund and Snee 1988; Selverstone et al. 1992; Getty et al. 1993; Gray and Oldow 2005; Blake et al. 2009; Gray et al. 2012). The western structural boundary of the Salmon River belt is the Heavens Gate fault, an east-dipping thrust fault that was reactivated as a down-to-the-east normal fault during Tertiary extension (Gray and Oldow 2005; Blake et al. 2009; Gray et al. 2012). The Heavens Gate fault directly juxtaposes hanging-wall greenschist-grade tectonites of the Salmon River fold-thrust belt against unmetamorphosed to low-grade footwall rocks of the Wallowa terrane, including the CHF. Rocks in the Salmon River fold-thrust belt appear to be metamorphosed equivalents of BMP supracrustal rocks (Baker, Izee, and Olds Ferry terranes), although protolith ages and terrane affinities remain poorly understood (e.g., Lund and Snee 1988; Blake 1991; Selverstone et al. 1992; Getty et al. 1993; Gray and Oldow 2005; Lund et al. 2007; Blake et al. 2009; Schmidt et al. 2013).

The Salmon River fold-thrust belt is bounded on the east by the western Idaho shear zone (fig. 2), a narrow, subvertical zone of tectonized Late Cretaceous-Early Tertiary plutons coincident with a sharp $\mathrm{Sr}_{\mathrm{i}}$-isotopic boundary that defines the edge of the preaccretion North American continental margin (Armstrong et al. 1977; Giorgis et al. 2005). Late Cretaceous deformation in the western Idaho shear zone resulted in sharp structural and isotopic truncation of the North American margin and completely obscures original contact relationships at the convergent margin between accreted terranes of the BMP and the North American craton (Lund and Snee 1988; McClelland et al. 2000; Giorgis et al. 2005, 2008; Blake et al. 2009).

Jurassic Tectonic Setting. The traditional model (fig. 3A) for the Middle-Late Jurassic tectonic setting of the BMP consists of (1) Early-Middle Jurassic noncollisional offshore subduction beneath the facing Wallowa and Olds Ferry arc terranes and (2) Late 

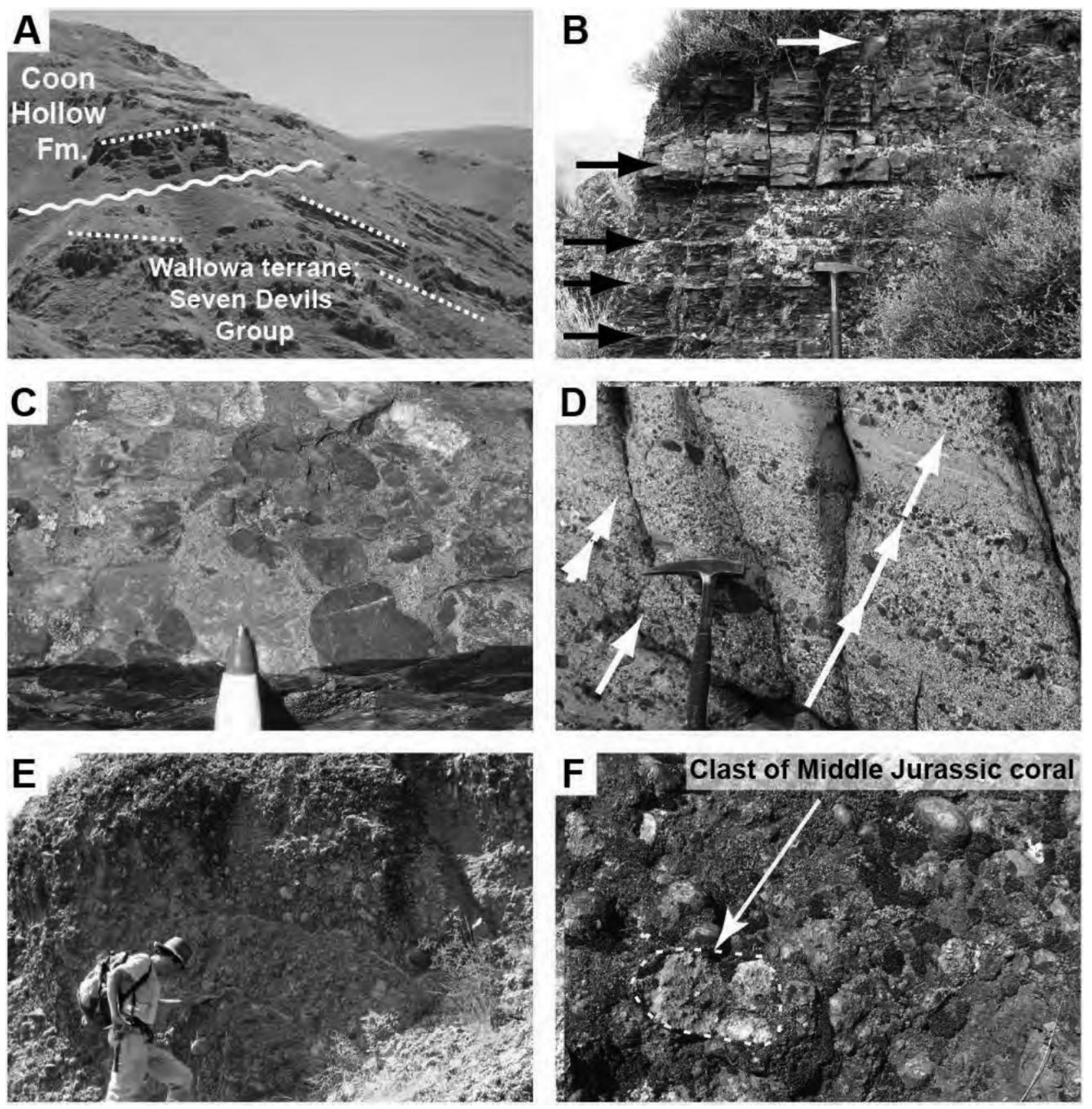

Figure 5. Field photographs of the Coon Hollow Formation and the red tuff unit. A, Angular unconformity between the Seven Devils Group and overlying Coon Hollow Formation, Idaho side of Snake River south of Big Cougar Creek (river mile 179.5). B, Thin-bedded to laminated ammonite-bearing shale with interbedded fine sandstone (arrows) in the Coon Hollow Formation lower flysch unit, type locality. C, Chert-clast conglomerate in the Coon Hollow Formation upper flysch unit, type locality. $D$, Medium-bedded, normally graded beds of tuffaceous volcanic-clast conglomerate and volcaniclastic sandstone, red tuff unit, Pittsburg Landing, Idaho. E, Massive conglomerate of the Coon Hollow Formation fluvial unit, Pittsburg Landing, Idaho. F, Detrital clast of coral in the Coon Hollow Formation fluvial unit, Pittsburg Landing, Idaho. A color version of this figure is available online.

Jurassic offshore collision of the Wallowa terrane with the Olds Ferry, Izee, and Baker terranes (Dickinson 1979, 2004; Avé Lallemant 1995; Schwartz et al. 2010, $2011 a, 2011 b$, 2014), followed by (3) later accretion of the amalgamated Blue Mountain terranes to the western North American craton ca. 128 Ma during strong crustal shortening and peak metamorphism in the Salmon River belt (Getty et al. 1993; Schwartz et al. 2011a). Age constraints for Late Jurassic deformation come from the youngest detrital zircons 

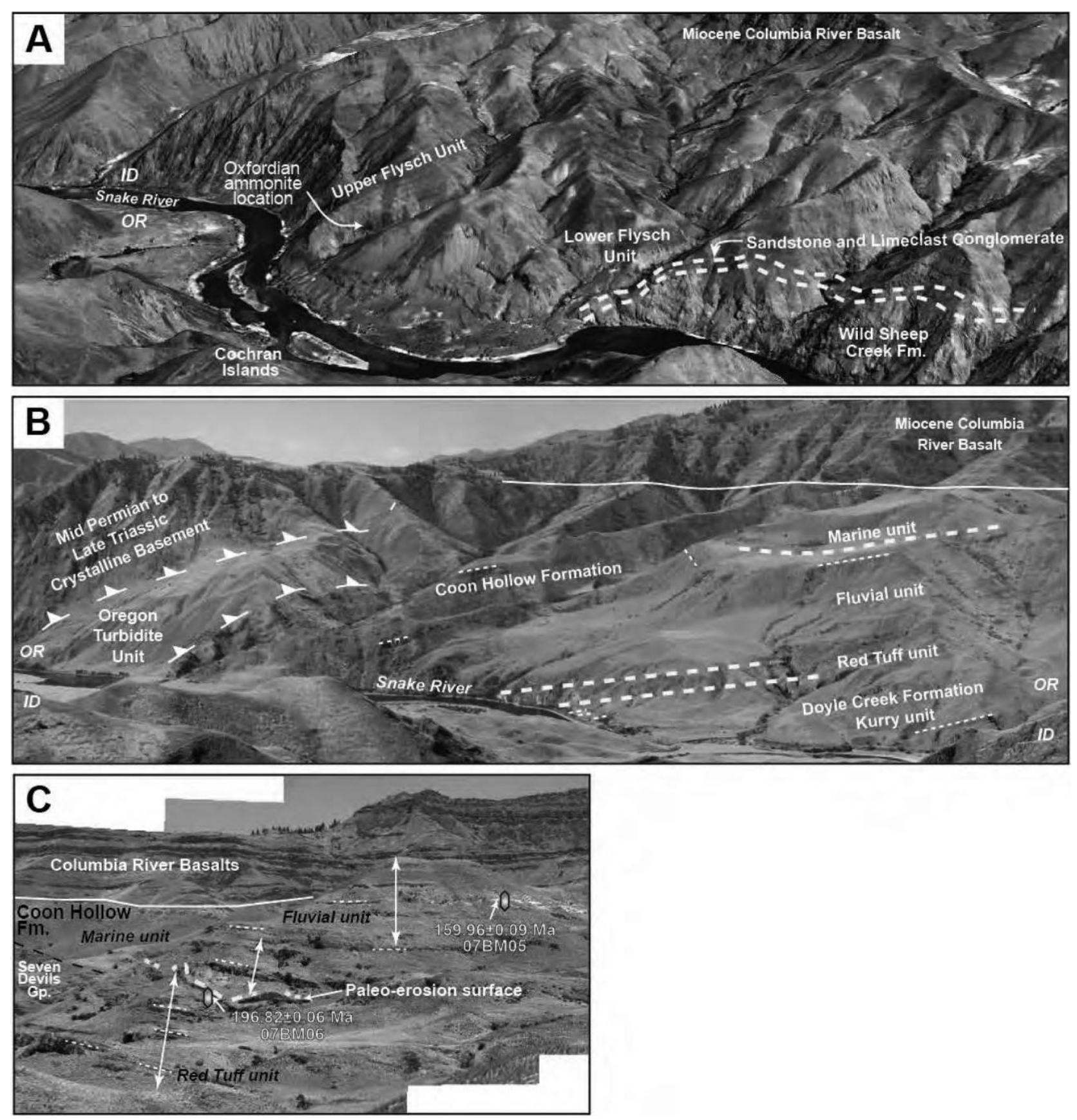

Figure 6. Images of type and Pittsburg Landing localities showing stratigraphic and structural setting. A, Coon Hollow type location (Google Image (C) 2011 DigitalGlobe). View looking northeast across the Snake River into Idaho. Adapted from Morrison (1963) and unpublished mapping. B, Pittsburg Landing. View looking southeast along West Creek, Idaho, across the Snake River into Oregon. Adapted from Vallier (1998), Schmidt et al. (2009), and unpublished mapping. C, View of Early Jurassic red tuff unit overlain by the Late Jurassic Coon Hollow Formation fluvial. View looking north. Location and ages of chemical abrasion isotope dilution thermal ionization mass spectrometry U-Pb zircon geochronology samples are shown. A color version of this figure is available online.

in deformed sedimentary rocks of the Izee terrane (ca. $159 \pm 2 \mathrm{Ma}$ ) and crystallization ages of postkinematic plutons (ca. $154 \pm 1 \mathrm{Ma}$ ) in the Baker terrane (Schwartz et al. 2011a). Plutonic rocks in the Baker terrane bracket this time frame and re- cord a transition from low Sr/Y magmatism ca. 162$157 \mathrm{Ma}$ to high Sr/Y magmatism ca. 148-145 Ma, which has been interpreted to represent crustal thickening due to arc-arc collision (Schwartz et al. 2011a, 2014). 
A different tectonic model (fig. 3B) involves (1) Late Triassic-Early Jurassic offshore collision (amalgamation) of the Wallowa terrane with the Olds Ferry, Izee, and Baker terranes and (2) Middle Jurassic accretion and collision of the previously amalgamated Wallowa-Baker-Olds Ferry-Izee terranes to the western US plate margin, followed by (3) Late Jurassic postaccretion outboard subduction (e.g., Dorsey and LaMaskin 2007, 2008; LaMaskin et al. 2008a, 2011a, 2011b; LaMaskin 2012). This second model proposes that collisional tectonics played a significant role in the development of the BMP but that collision was complete by ca. $160 \mathrm{Ma}$ (earliest Late Jurassic).

A long-standing point of agreement in the geology of the region has been correlation of the CHF in Hells Canyon (Wallowa terrane) with Middle Jurassic Izee terrane rocks of the John Day Oregon region(e.g., Pessagno and Blome 1986; White et al. 1992; Dickinson 2004, 2008; Dorsey and LaMaskin 2007, 2008; LaMaskin et al. 2008a). This correlation has led to the interpretation of a regional Middle Jurassic sedimentary overlap assemblage (Blue Mountain collisional basin, Izee basin) as evidence for preMiddle Jurassic amalgamation of the Blue Mountain terranes.

In contrast, the age of accretion of the Blue Mountain amalgamated arc terranes to western North America remains a long-standing point of contention, with interpretations ranging from ca. 165 to $118 \mathrm{Ma}$, an uncertainty of $45 \mathrm{~m} . y$ r. (e.g., Lund and Snee 1988; Selverstone et al. 1992; Getty et al. 1993; Snee et al. 1995, 2007; Gray and Oldow 2005; Dorsey and LaMaskin 2007, 2008; Schwartz et al. 2010, $2011 a, 2011 b$, 2014). Early work interpreted ca. 118 Ma ages on deformed hornblende from the Salmon River fold-thrust belt as metamorphic crystallization ages, suggesting that suturing (collision) of BMP terranes and North American continental rocks occurred between $\sim 118$ and $95 \mathrm{Ma}$ during regional metamorphism, crustal shortening, thickening, and mountain building (Lund and Snee 1988). In contrast, Selverstone et al. (1992) argued that the ca. 118 $\mathrm{Ma}$ age is a cooling age. They concluded on the basis of geothermometry and geobarometry that (1) deep tectonic burial of Blue Mountain terranes via underthrusting beneath the North American margin occurred during Early Cretaceous time ca. $130 \pm 5 \mathrm{Ma}$ and (2) rapid exhumation and cooling due to detachment and sinking of mantle lithosphere began ca. $120 \pm 5 \mathrm{Ma}$. Selverstone et al. (1992) also suggested that collision-related thrusting in the Salmon River fold-thrust belt may have been under way as early as $160 \mathrm{Ma}$. On the basis of Sm-Nd dating of garnet, Getty et al. (1993) proposed that two distinct metamorphic stages are recorded in Salmon River rocks: (1) the Blue Mountain terranes were amalgamated offshore prior to ca. $144 \mathrm{Ma}$, and (2) regional peak metamorphism in the Salmon River fold-thrust belt was reached ca. $128 \mathrm{Ma}$. Subsequent ${ }^{40} \mathrm{Ar} /{ }^{39} \mathrm{Ar}$ studies in Idaho have been interpreted to suggest that the oldest deformation in the region occurred ca. $130 \mathrm{Ma}$ (Snee et al. 1995, 2007). Finally, a U-Pb age of $136 \pm 1 \mathrm{Ma}$ on a deformed pluton in the hanging wall of the Heavens Gate fault has been interpreted to reflect post-136 Ma accretion (Gray et al. 2012; Gray 2013).

Field-based stratigraphic and structural analysis has been used to argue that pre-Cretaceous docking of the Wallowa terrane is recorded in widespread Late Jurassic contractional structures bracketed between 157 and $145 \mathrm{Ma}$ (Gray and Oldow 2005). In this view, Late Jurassic accretionary deformation is superposed on an earlier deformation history in the Salmon River fold-thrust belt that is related to structural closure of a fringing arc (Izee-Olds FerryBaker terranes) and a now-consumed back-arc basin in Oregon and Idaho (Gray and Oldow 2005).

Stratigraphy of the CHF. At its type locality (figs. 2, $4,6 A$ ), the CHF is divided into three conformable map units: (1) basal volcaniclastic sandstone and limestone-clast conglomerate ( 20-60 m thick), (2) volcaniclastic lower flysch unit ( 80 m thick; figs. 5B, 7A-7C), and (3) chert-rich upper flysch unit ( 300 m thick; figs. 5C, 7D; Morrison 1963; Goldstrand 1994). The lower flysch unit at the type locality has been assigned an early Late Jurassic, $\mathrm{Ox}$ fordian age (ca. $163.5 \pm 1.1$ to $157.3 \pm 1.0 \mathrm{Ma}$ ) on the basis of the ammonite Cardioceras (Scarburgiceras) martini collected $\sim 125 \mathrm{~m}$ above the contact with the underlying Seven Devils Group (table 1).

At the Pittsburg Landing locality (figs. 2, 4, 6B), deposits traditionally mapped as the CHF are divided into three units: (1) red tuff unit ( 120 m thick; figs. $5 D, 6 C)$, (2) fluvial unit $(\sim 20 \mathrm{~m}$ thick; figs. $5 D-$ $5 F, 6 C, 7 E)$, and (3) marine unit $(100 \mathrm{~m}$ thick; fig. $6 C$; White 1994; White and Vallier 1994). The red tuff unit is lithologically dominated by pink volcaniclastic to epiclastic, monomict sandstone and conglomerate; includes welded tuff in its upper parts (White 1986); and is overlain by polymict brown sandstone and conglomerate and yellow-weathering mudstone of the fluvial unit along a moderate angular unconformity (figs. $5 E, 6 B, 6 C, 7 F$ ). The fluvial unit is gradationally overlain by black shale and mudstone of the marine unit, which in turn grades upsection into chert-rich volcaniclastic sandstone (fig. $6 B$, $6 C$ ). The marine unit contains a fauna including coral taxa identified by Stanley and Beauvais (1990) as Middle Jurassic in age (Bajocian, $170.3 \pm 1.4$ to 

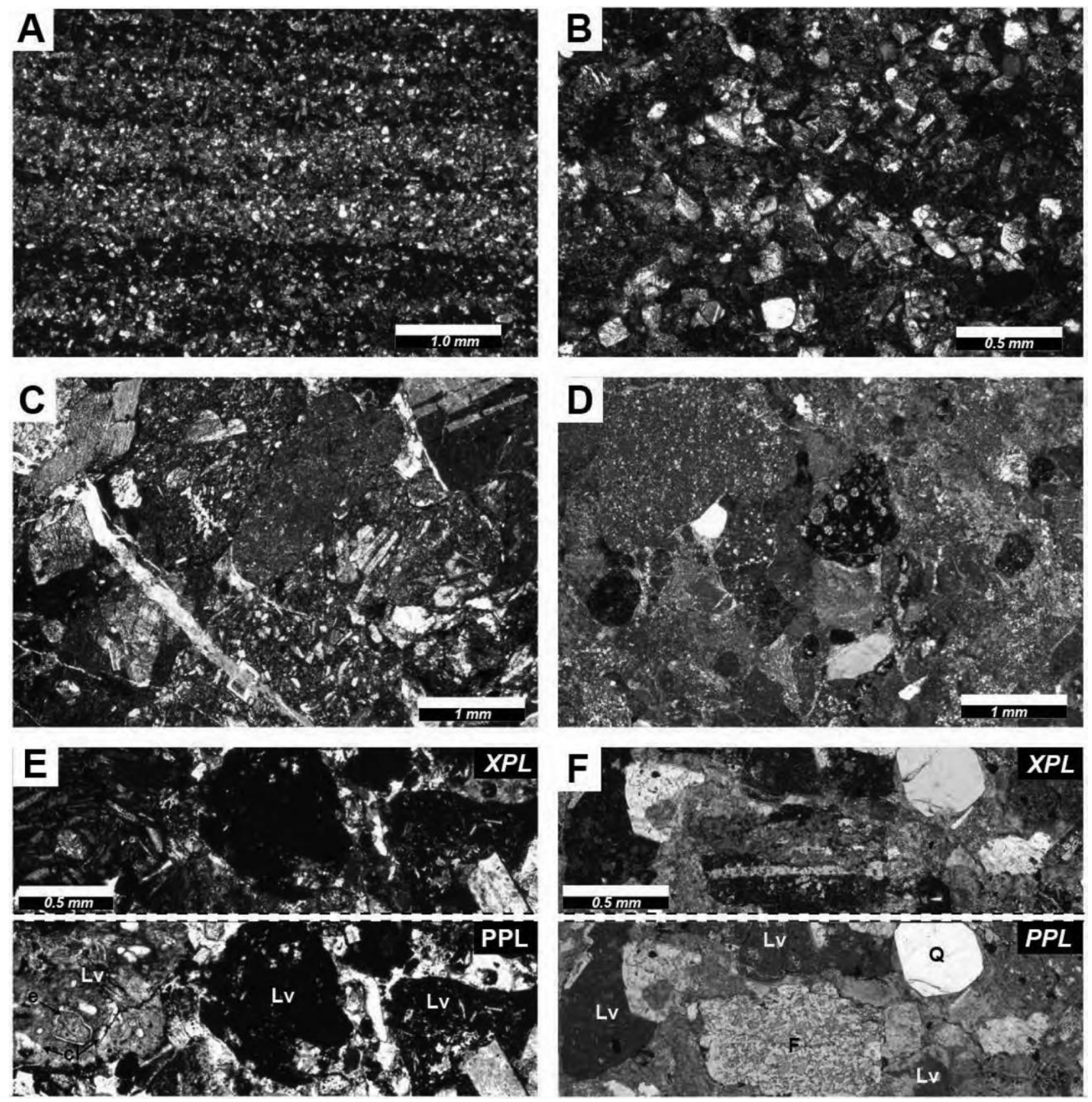

Figure 7. Photomicrographs of key sandstone petrofacies. A, Laminated, very-fine quartzolithic sandstone, Coon Hollow Formation, lower flysch unit, type locality. Cross-polarized light. B, Fine quartzolithic sandstone, Coon Hollow Formation, lower flysch unit, type locality. Cross-polarized light. C, Volcanic-lithic sandstone of the Coon Hollow Formation, lower flysch unit, type locality. Cross-polarized light. $D$, Chert-grain lithic sandstone, Coon Hollow Formation, upper flysch unit, type locality. Cross-polarized light. E, Plane light (PPL; bottom) and cross-polarized (XPL; top) view of the red tuff unit showing a variety of volcanic lithic grains (Lv) as well as epidote (e) and chlorite (cl) alteration. F, Plane light (PPL; bottom) and cross-polarized (XPL; top) view of sandstone from the Coon Hollow Formation fluvial unit. Note the highly altered feldspar (F), faceted quartz (Q), and volcanic lithic grains (Lv). A color version of this figure is available online.

$168.3 \pm 1.3 \mathrm{Ma}$ ). Thus, the transgressive, fluvial- to deep-marine CHF has traditionally been regarded as Middle to early Late Jurassic in age (BajocianOxfordian; ca. $170.3 \pm 1.4$ to $157.3 \pm 1.0 \mathrm{Ma}$; fig. 8 ; table 1). Here, we present evidence that clearly con- tradicts this interpretation and demonstrate a robust Late Jurassic depositional age for the CHF.

A fourth unit, the turbidite unit of the Coon Hollow Formation (White and Vallier 1994), is present on the Oregon side of Pittsburg Landing (figs. 4, 6B). The 


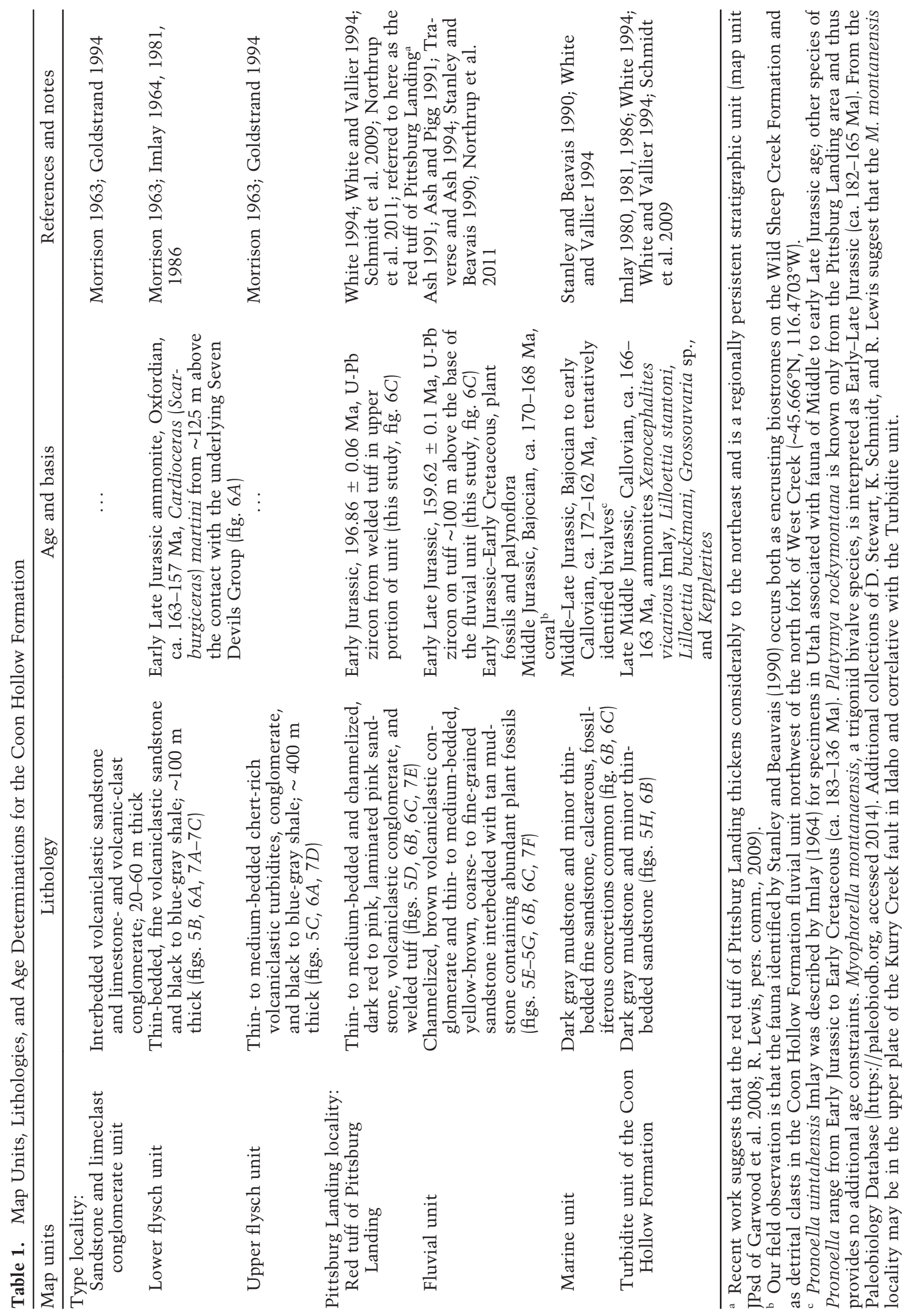




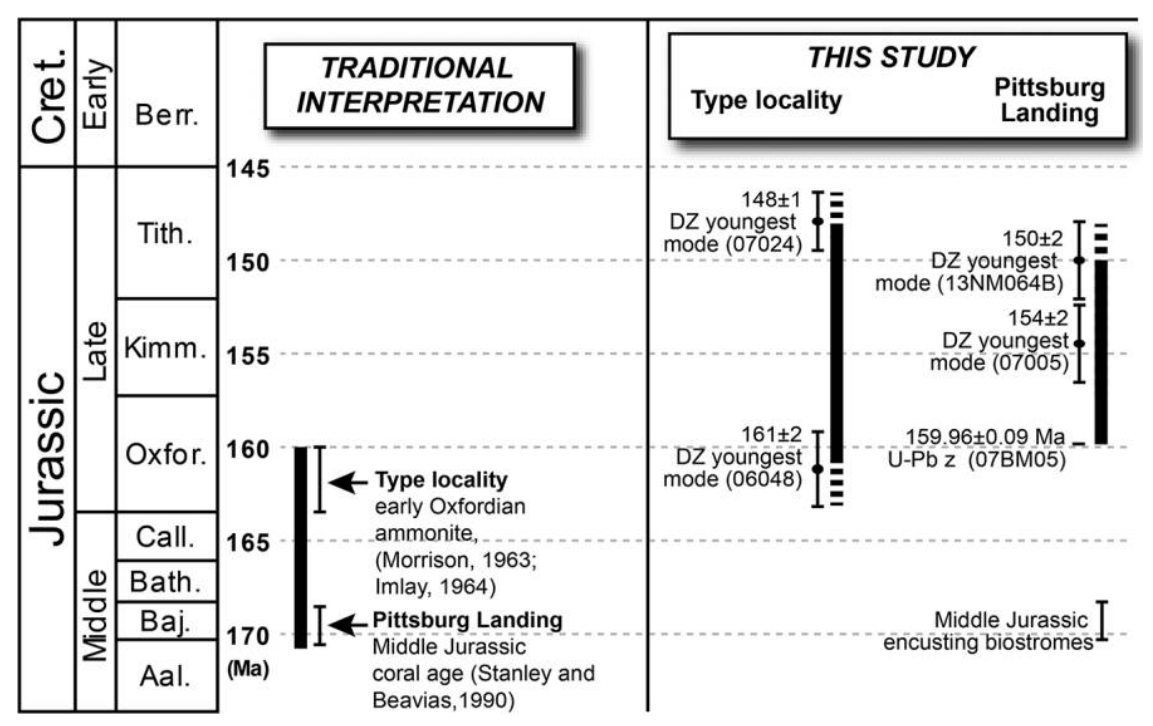

Figure 8. Depositional age range interpretations of the Coon Hollow Formation. Traditional age assignment is based on Middle Jurassic corals from the Pittsburg Landing locality and Late Jurassic ammonoids at the type locality. New $\mathrm{U}-\mathrm{Pb}$ geochronology presented here indicates that deposition spanned ca. 160-150 Ma, entirely within Late Jurassic time.

turbidite unit is dated with ammonoids as late Middle Jurassic (Callovian, ca. $166.1 \pm 1.2$ to $163.5 \pm 1.1$; Imlay 1980, 1981, 1986; table 1) and is present in the upper plate of a thrust fault that structurally overlies and thus is likely older than the fluvial unit (Schmidt et al. 2009). Data presented here are only from the Idaho side of Pittsburg Landing.

\section{Methods}

Sampling Strategy. Our sampling strategy for $\mathrm{U}-\mathrm{Pb}$ detrital zircon analysis, Sm-Nd isotopic analysis, and high-precision U-Pb geochronology was designed to (1) define the depositional age of key rock units, (2) test proposed regional correlation of the CHF with Middle Jurassic rocks of the John Day region, (3) evaluate potential provenance links of the CHF to continental and arc-related sources, and (4) evaluate provenance links to other rocks of the western United States (sample location information is in table 2).

We targeted two volcanic units of pyroclastic origin from the Pittsburg Landing locality for chemical abrasion isotope dilution thermal ionization mass spectrometry (CA-ID-TIMS) U-Pb zircon geochronology to establish eruption and depositional ages for the surrounding strata (figs. 4, 6C). In the uppermost volcanic horizon of the red tuff unit, immediately below the fluvial unit unconformity, we sampled densely welded quartz and plagioclase-phyric rhyolite tuff (07BM06) with strongly flattened pumice fiamme. In addition, we collected a sample from ap- proximately $100 \mathrm{~m}$ above the base of the fluvial unit from normally graded, hornblende-phyric, lithic lapilli tuff (07BM05) containing subangular to subrounded millimeter- to centimeter-scale volcanic clasts in a tuffaceous matrix with abundant accretionary lapilli.

For detrital zircon analysis, we collected four 5$10-\mathrm{kg}$ samples of sandstone (fig. 4). At the type locality, we collected fine-grained, thinly laminated volcaniclastic lithic arenite from near the base of the lower flysch unit (sample 06048) and mediumgrained, thin-bedded chert-grain lithic arenite from the top of the upper flysch unit (sample 07024). At Pittsburg Landing, we collected medium-grained volcaniclastic lithic arenite from the uppermost fluvial unit (sample 07005) and medium-grained, thinbedded chert-grain lithic arenite from the top of the marine unit (13NM064B). We also collected 0.25-kg samples of fluvial and marine mudrock for Sm-Nd analysis and sandstone samples for petrographic analysis to assess the relationship between sandstone petrofacies and detrital zircon ages (fig. 4).

Analytical Procedures. U-Pb zircon geochronology by CA-ID-TIMS was conducted at Boise State University following the methods of Schmitz and Davydov (2012). High-precision U-Pb zircon results are presented on conventional Wetherill concordia diagrams (fig. 9) and in table 3. Rapid-acquisition $\mathrm{U}-\mathrm{Pb}$ detrital zircon analysis was conducted by laser ablation inductively coupled plasma mass spectrometry (LA-ICP-MS) at Washington State University following the method of Chang et al. (2006). U-Pb detri- 
Table 2. Sample Locations

\begin{tabular}{|c|c|c|c|}
\hline Sample no. & Sampled unit & Northing & Easting \\
\hline \multicolumn{4}{|l|}{ Type locality: } \\
\hline 06048 & $\begin{array}{l}\text { Lower flysch unit: laminated volcaniclastic sandstone from } \\
\sim 120 \text { m above the basal angular unconformity with the } \\
\text { underlying Wild Sheep Creek Formation }\end{array}$ & 5089844 & 0509606 \\
\hline 06049 & Base of flysch unit: black mudstone & 5090575 & 0509046 \\
\hline 06042 & Middle of flysch unit: black mudstone & 5090637 & 0508351 \\
\hline 07024 & $\begin{array}{l}\text { Upper flysch unit: chert-grain sandstone from uppermost } \\
\text { beds on ridge north of Little Cougar Creek }\end{array}$ & 5091178 & 0509022 \\
\hline 07023 & Upper flysch unit: black mudstone & 5091205 & 0509275 \\
\hline \multicolumn{4}{|c|}{ Pittsburg Landing locality: } \\
\hline $06075^{\circ}$ & $\begin{array}{l}\text { Red tuff of Pittsburg Landing: medium-grained reworked } \\
\text { lithic lapillistone }\end{array}$ & 5054973 & 0541002 \\
\hline 07BM06 & Red tuff of Pittsburg Landing: welded tuff & 5055068 & 0541138 \\
\hline 07BM05 & Fluvial unit: lapilli tuff & 5055130 & 0541356 \\
\hline 06060 & Upper portion of fluvial unit: yellow-plant-bearing mudstone & 5056298 & 0541936 \\
\hline 07005 & Upper portion of fluvial unit: channelized volcaniclastic sandstone & 5056308 & 0541940 \\
\hline 06056 & Marine unit: black mudstone bearing marine molluscan fauna & 5056586 & 0541994 \\
\hline 13NM064B & Upper portion of marine unit, chert-grain sandstone & 5057400 & 0545224 \\
\hline
\end{tabular}

Note. UTM datum NAD 27 CONUS, UTM zone 11.

tal zircon ages are illustrated on relative probability and Tera-Wasserberg plots (fig. 10) and in the supplementary data (available online). For determination of isotopic composition of Sm and Nd (fig. 11; table 4), fresh samples were ground to $<30-\mu \mathrm{m}$ powder, and Sm and $\mathrm{Nd}$ were separated following the methods described in Vervoort and Blichert-Toft (1999) and in Gaschnig et al. (2011). The isotopic compositions of these elements were analyzed on a ThermoFinnigan Neptune multicollector ICP-MS at Washington State University (see Gaschnig et al. 2011).

Depositional Age Assessment. The potential for a short or a long lag time between crystallization and deposition of the youngest detrital grain(s) in a sample renders the assessment of depositional age from detrital mineral data inherently problematic (i.e., a maximum depositional age). We assessed our samples' depositional ages by comparing published faunal ages to the mean age and standard error of the youngest mode of the detrital zircon probability distribution function obtained by deconvolution using the mixture-modeling approach (Sambridge and Compston 1994; i.e., Unmix function of IsoPlot/ Ex 3.00 [Ludwig 2003]). This approach is analogous to the youngest graphical age peak of Dickinson and Gehrels (2009) but includes a statistical assessment of the margin of error. We consider the youngest age mode of a probability density estimate of the data (i.e., the youngest multigrain estimate of central tendency) to be the most conservative, robust, and unbiased estimator of maximum depositional age from detrital data. Unfortunately, maximum depositional ages assigned on the basis of the youngest single grain in a sample cannot be reasonably com- pared with the chronometric time scale, which is itself generated from estimates of central tendency (cf. Schmitz 2012).

\section{Results}

CA-ID-TIMS U-Pb Geochronology. Densely welded tuff of the red tuff unit produced prismatic volcanic zircon, from which six single crystals yielded concordant and equivalent isotopic ratios with a weighted mean ${ }^{206} \mathrm{~Pb} /{ }^{238} \mathrm{U}$ date of $196.82 \pm 0.06 \mathrm{Ma}$ $(2 \sigma ; \mathrm{MSWD}=0.48)$ by CA-ID-TIMS (figs. 4, 6C, 9A). Another crystal produced a slightly (ca. $0.3 \mathrm{Ma}$ ) but resolvably older date interpreted as biased by minor inheritance. The weighted mean age is within the Sinemurian stage (Early Jurassic) and is interpreted as the eruption and deposition age of the tuff bed.

The sample of lapilli tuff (07BM05) from $\sim 100 \mathrm{~m}$ above the base of the fluvial unit (figs. 4, 6C, 9B) produced a relatively small amount of zircon, from which 10 crystals were selected for CA-ID-TIMS. Four grains yielded a range of older, concordant ages from 235 to $172 \mathrm{Ma}$, which are obviously inherited. The remaining six analyses fall into two barely resolvable clusters; all six grains yield a weighted mean of $160.16 \pm 0.21 \mathrm{Ma}(95 \%$ confidence interval $; \mathrm{MSWD}=$ 8.2) during the Oxfordian stage (Late Jurassic). The younger three grains have a weighted mean ${ }^{206} \mathrm{~Pb} /{ }^{238} \mathrm{U}$ date of $159.96 \pm 0.09 \mathrm{Ma}(2 \sigma ; \mathrm{MSWD}=0.82)$; given the evidence of inheritance, $159.96 \pm 0.09 \mathrm{Ma}$ (i.e., $160 \mathrm{Ma}$ ) is the preferred eruption and depositional age.

Detrital Zircon Geochronology. Our sample from the type locality at the base of the CHF lower flysch unit (fig. 10A, sample 06048), contains a multimodal 

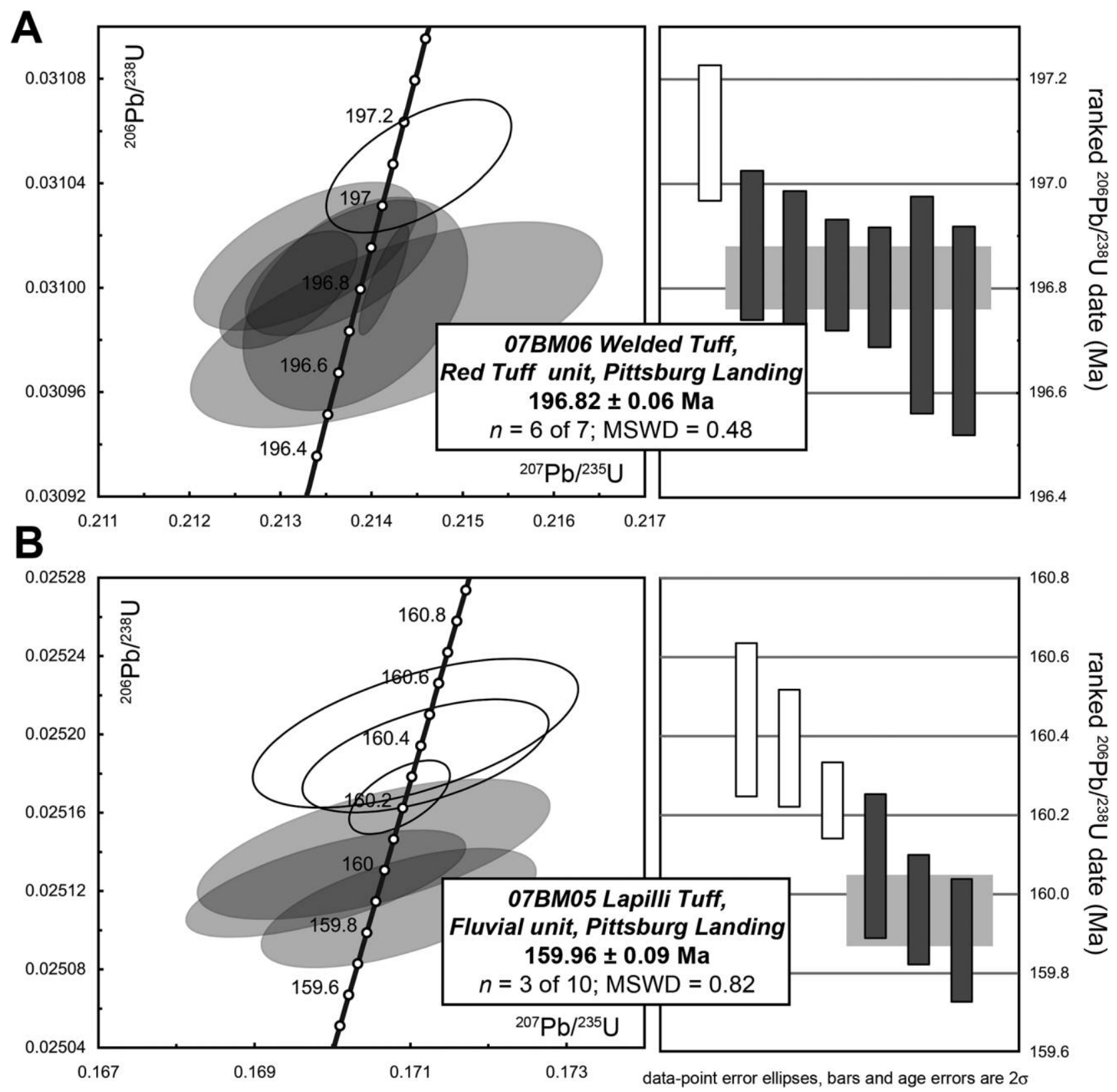

Figure 9. U-Pb concordia diagrams and weighted mean plots of magmatic zircon analyses. $A$, Sample 07BM06, red tuff unit at Pittsburg Landing. B, Sample 07BM05, fluvial unit of the Coon Hollow Formation. For both illustrations, zircon analyses included in the calculation of the weighted mean ${ }^{206} \mathrm{~Pb} / 238 \mathrm{U}$ crystallization age are represented by gray ellipses on Concordia diagrams and by gray error bars on weighted mean plots. Open, black-outlined ellipses and error bars were not used in any age calculation. All errors are shown at $2 \sigma$. The gray band set behind each group on the weighted mean plots represents the calculated weighted mean of those analyses and its associated $2 \sigma$ uncertainty.

probability distribution dominated by Early PermianLate Triassic ages (ca. 290-210 Ma) with lesser EarlyLate Jurassic ages (ca. 200-180, 180-170, and 165-155 $\mathrm{Ma})$. Six zircons from this sample have pre-Permian ages that do not overlap at $2 \sigma$ and are not illustrated here $(362 \pm 15,508 \pm 11,932 \pm 41,1189 \pm 33,1284 \pm$ 39 , and $1506 \pm 41 \mathrm{Ma}$ ). The youngest deconvolved mode of the probability distribution is $161 \pm 3 \mathrm{Ma}$ (Oxfordian-Kimmeridgian).

Medium-grained chert-grain sandstone from the type locality at the top of the CHF upper flysch unit (fig. 10B, sample 07024) contains an essentially bimodal age distribution with ages spanning EarlyLate Triassic (ca. 240-210 Ma) and Late Jurassic- 


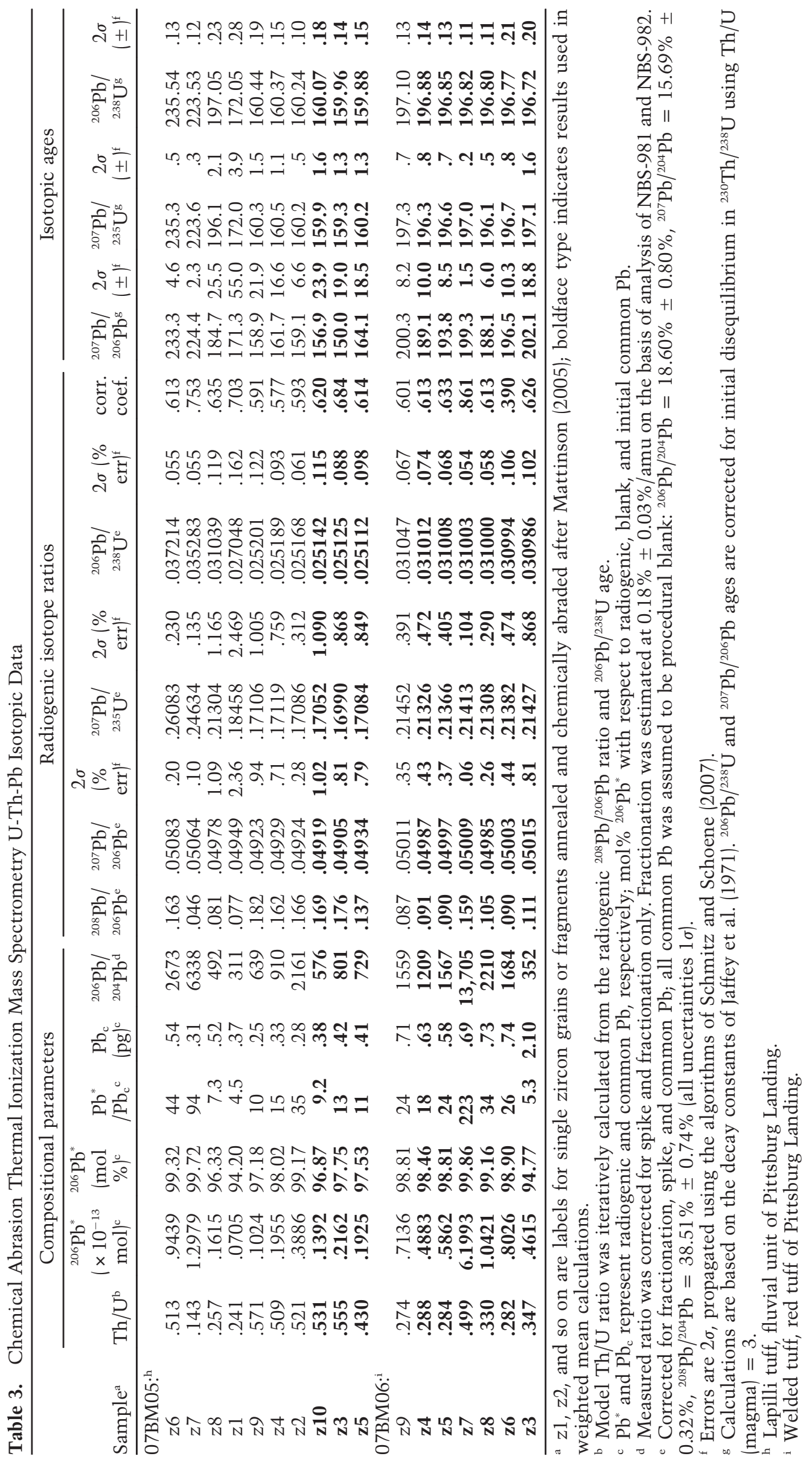



Aoon Hollow Fm., sample 06048 , base of lower
flysch unit, type locality, $n=107$
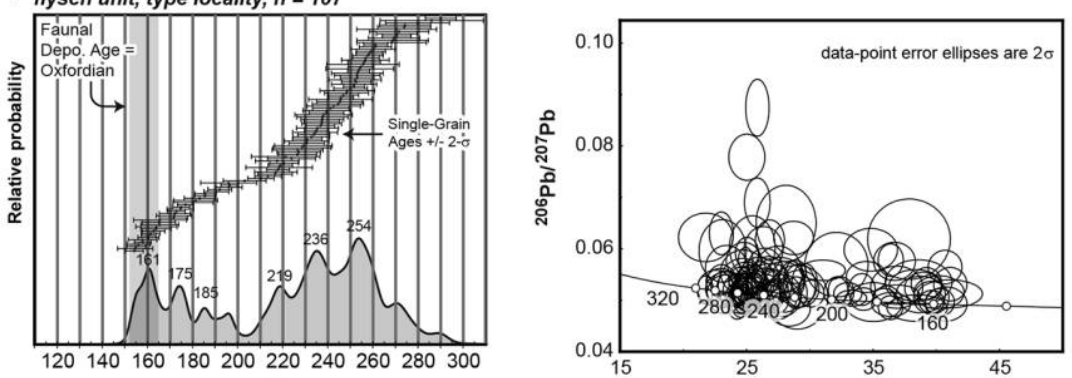

Coon Hollow Fm., sample 07024, top of upper flysch unit, type locality, $n=38$
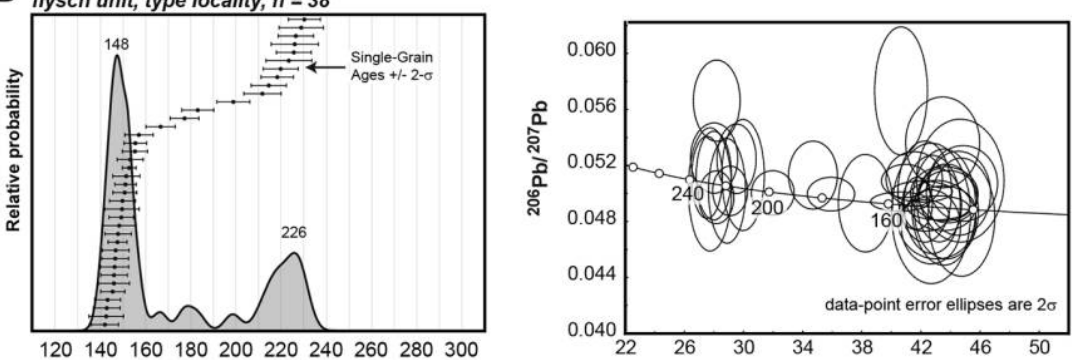

C Red tuff unit at Pittsburg Landing, sample
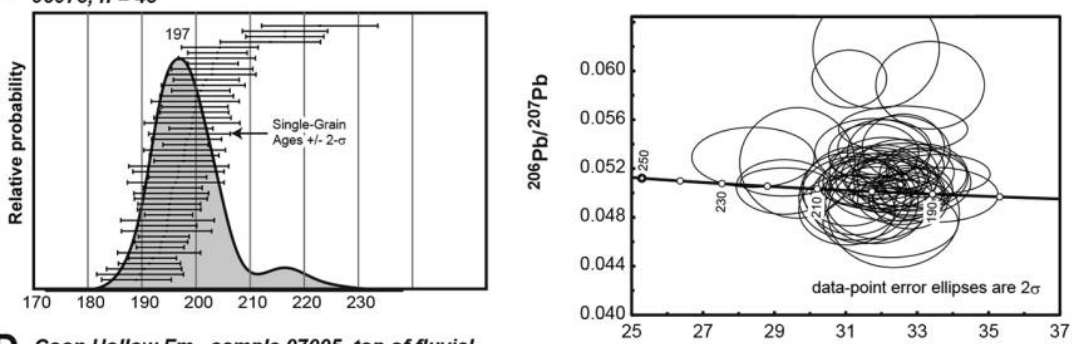
D Coon Hollow Fm., sample 07005, top of fluvial
unit at Pittsburg Landing, $n=138$
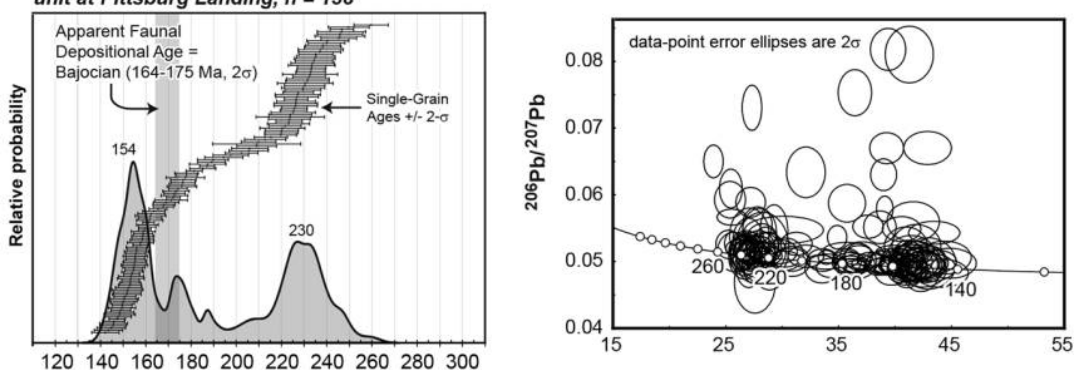

E Coon Hollow Fm., sample 13NM064B, top of
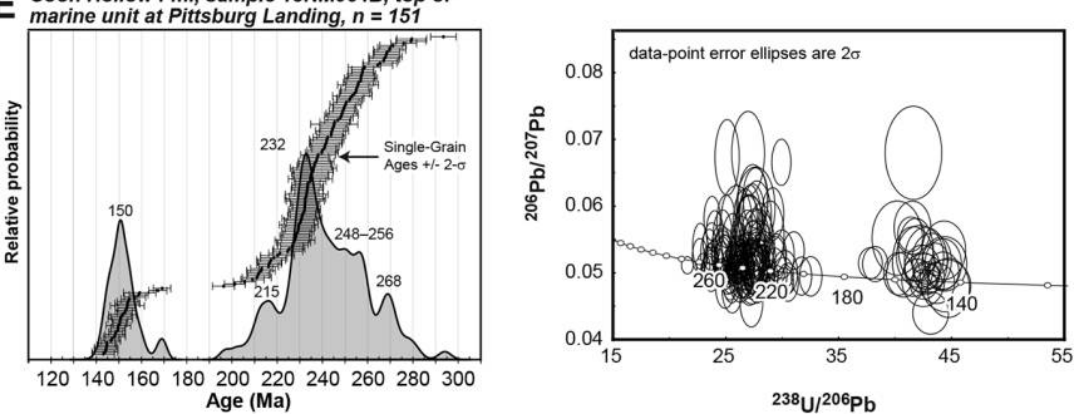

Figure 10. U-Pb detrital zircon data shown on relative probability diagrams (left) and Tera-Wasserberg diagrams (right). A, Sample 06048, collected from basal, thin-bedded turbidite sandstones in the Coon Hollow Formation lower flysch unit, type locality. $B$, Sample 07024, collected from uppermost chert-grain sandstone in the Coon Hollow Formation upper flysch unit, type locality. $C$, Sample 06075, collected from lithic arenite near the base of the red tuff unit, Pittsburg Landing. $D$, Sample 07005, collected from volcaniclastic sandstone beds near the top of the Coon Hollow Formation fluvial unit, Pittsburg Landing. E, Sample 13NM064B, collected from uppermost chert-grain sandstone in the Coon Hollow Formation marine unit, Pittsburg Landing. 


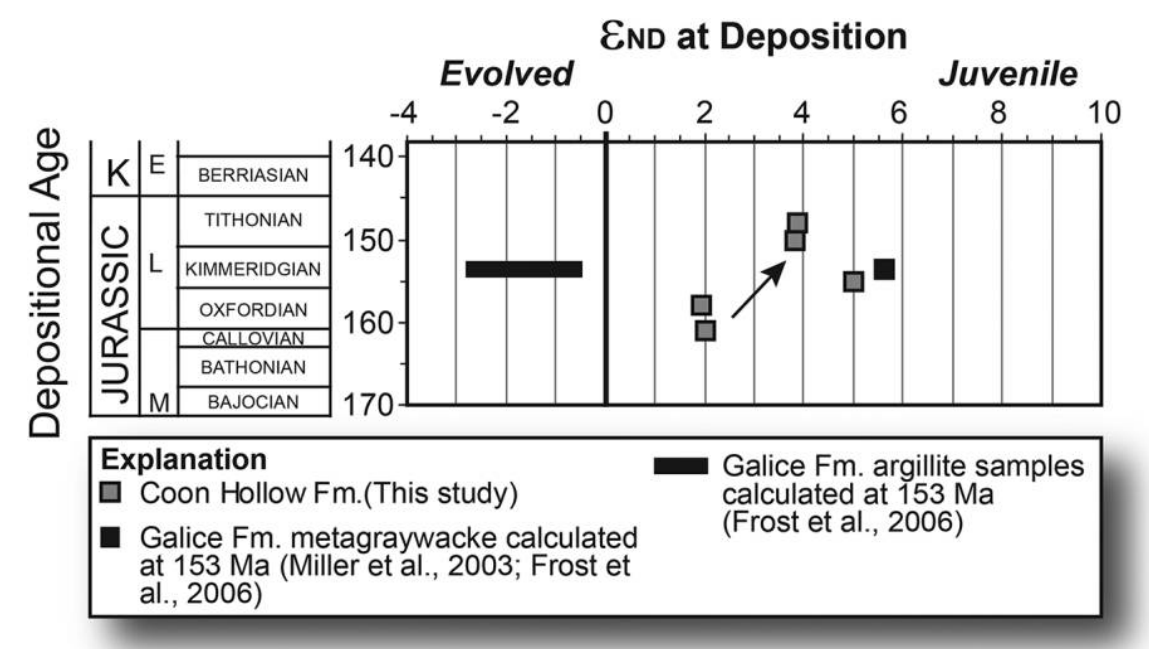

Figure 11. Plot of $\epsilon_{\mathrm{Nd}}$ at deposition versus depositional age for mudrock samples of the Coon Hollow Formation (gray squares). Also shown are values from Miller et al. (2003) and Frost et al. (2006) for the Galice Formation (black square and rectangle).

Early Cretaceous (ca. 165-142 Ma) time. A single zircon grain from this sample has a pre-Mesozoic age $(656 \pm 12 \mathrm{Ma})$. The youngest mode of the probability distribution is $148 \pm 1 \mathrm{Ma}$ (Tithonian).

A Pittsburg Landing lithic arenite collected within the red tuff unit exhibits a bimodal age distribution that spans ca. 223-214 and 205-189 Ma (Late Triassic-Early Jurassic; fig. 10C). The youngest mode of the probability distribution is $197 \pm 1 \mathrm{Ma}$ (Sinemurian). Also from the Pittsburg Landing locality, the uppermost fluvial volcaniclastic rocks of the CHF (fig. 10D, sample 07005) contain a relatively simple multimodal age distribution spanning (1) Early-Late Triassic (ca. 250-210 Ma), (2) EarlyMiddle Jurassic (ca. 180-170 Ma), and (3) Late JurassicEarly Cretaceous (ca. 165-142 Ma) ages. Four zircon grains from this sample have pre-Mesozoic ages that do not overlap at $2 \sigma$ and are not illustrated here $(260 \pm 6,1322 \pm 34,1745 \pm 15$, and $1814 \pm 30 \mathrm{Ma})$. The youngest deconvolved mode of the probability distribution is $154 \pm 2 \mathrm{Ma}$ (Tithonian).

Finally, medium-grained chert-grain sandstone from the uppermost beds in the CHF at Pittsburg Landing (fig. 10E, sample 13NM064B) contains a multimodal probability distribution dominated by Early PermianLate Triassic ages (ca. 290-210 Ma) with age modes ca. 268, 256-248, 232, and $215 \mathrm{Ma}$, with lesser EarlyLate Jurassic ages (ca. $175 \mathrm{Ma}$ and 165-143 Ma). No zircon grains from this sample have pre-Permian ages. The youngest mode of the probability distribution is $150 \pm 2 \mathrm{Ma}$ (Tithonian).

Neodymium Isotope Compositions. Our Coon Hollow $\epsilon_{\mathrm{Nd}}$ values are moderately radiogenic, with val- ues ranging between 1.9 and 5.0. The data display a moderate age-dependent trend toward more juvenile values over the $\sim 10 \mathrm{Ma}$ time span from ca. 160 to $150 \mathrm{Ma}$ (fig. 11 ; table 4).

\section{Discussion}

Early Jurassic Depositional Age of Red Tuff. We report two new Early Jurassic, Sinemurian ages for the red tuff. The age of $196.82 \pm 0.06 \mathrm{Ma}$ on welded tuff from the top of the unit is within the mean and standard error $(197 \pm 1 \mathrm{Ma})$ of the youngest mode of the probability distribution from our corresponding detrital zircon sample (figs. 9B, 10C). The correspondence between CA-ID-TIMS and LA-ICP-MS zircon geochronology from the same unit indicates synmagmatic deposition and slight reworking of volcanic deposits. These results substantiate use of the youngest mode present in a detrital sample as an estimator of maximum depositional age from samples bearing zircon grains with ages approximating the time of host sediment accumulation / cf. Dickinson and Gehrels 2009). In such cases, the most conservative, robust, and unbiased estimator of maximum depositional age from detrital data is the youngest age mode of a probability density estimate of the data (i.e., the youngest multigrain estimate of central tendency).

Depositional Age of the CHF. The age of oldest $\mathrm{CHF}$ deposits can be estimated from the youngest detrital zircon age mode in basal marine turbidites at the type locality and from CA-ID-TIMS ages on interbedded tuff in basal fluvial rocks at Pittsburg 


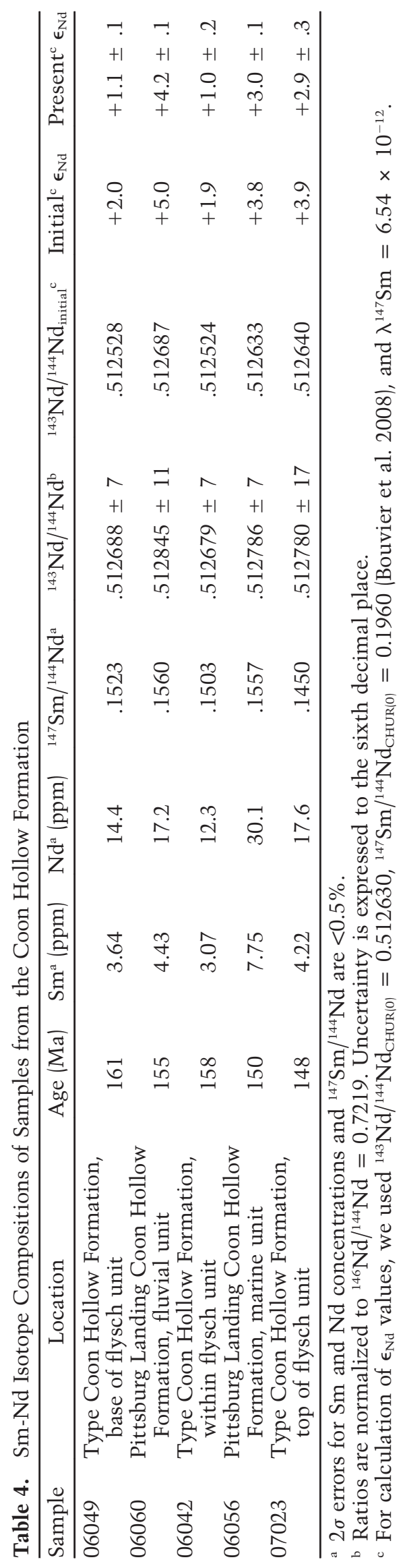


Landing (fig. 8). These units are age correlative, indicating that deposition of the CHF began ca. $160 \mathrm{Ma}$ (Late Jurassic, Oxfordian) at both locations. This represents both a maximum depositional age and a minimum age for (1) uplift and erosion of the underlying Wallowa terrane and (2) subsequent transgression of fluvial and marine rocks of the CHF (fig. 8). These new data, combined with new Early Jurassic age estimates for the red tuff (see Northrup et al. 2011), indicate that the angular unconformity that truncates the red tuff at Pittsburg Landing and rocks of the Seven Devils Group at the type locality represents a significant hiatus of approximately 37 m.yr. (figs. 4, 5A).

The minimum duration of sedimentation of the CHF can be estimated using correlative chert-grain sandstone in the uppermost beds of the CHF at the type locality (148 $\pm 1 \mathrm{Ma})$ and Pittsburg Landing (150 $\pm 2 \mathrm{Ma}$; fig. 8). These maximum depositional age estimates indicate that $\mathrm{CHF}$ deposition continued until at least ca. $150 \mathrm{Ma}$ (Late Jurassic, Tithonian) at both locations. Thus, deposition of the CHF spanned a 10-m.yr. period from 160 to $150 \mathrm{Ma}$ during Late Jurassic time.

All available geochronological data contradict and refute previous faunal estimates of a Middle Jurassic (Bajocian) to early Late Jurassic (Oxfordian) depositional age of the CHF (see also Northrup et al. 2011). We do observe in situ corals as thin, encrusting bioherms on rocks of the Late Triassic Wallowa terrane (Wild Sheep Creek Formation), and these bioherms appear to be the same taxa identified by Stanley and Beauvais (1990); however, at these locations the corals are also observed to be reworked as clasts within overlying fluvial conglomerate of the CHF (fig. 5F). Therefore, for the CHF, Middle Jurassic would be a detrital faunal age and, importantly, not a depositional age (cf. detrital faunal ages in LaMaskin et al. 2011a). This interpretation is consistent with descriptions of the corals as "broken, rounded, and reworked ... heavily bored" (Stanley and Beavais 1990, p. 353; see also White 1986, p. 116-118). Our field observations suggest that the thin, encrusting biostromes may, in fact, represent a period of Middle Jurassic deposition but that the inferred Middle Jurassic depositional age of the overlying CHF is inaccurate. All available U-Pb zircon geochronology shows clearly that the entire CHF is younger than Middle Jurassic age (fig. 8).

Provenance of the $\mathbf{C H F}$. In the basal transgressive lower flysch unit (fig. 10A, sample 06048), dominant Early Permian-Late Triassic ages (ca. 290-210 Ma) overlap with Wallowa terrane arc basement (265249; $215 \mathrm{Ma}$ ) and volcanic cover rock (229 Ma) ages, suggesting derivation from an uplifted, dissected Wal- lowa terrane source area during initial transgressive sedimentation. Less significant Early-Late Jurassic ages spanning ca. 200-180, 180-170, and 165-155 Ma are consistent with the range of Jurassic ${ }^{206} \mathrm{~Pb} /{ }^{238} \mathrm{U}$ ages recognized in plutons and volcanic beds in the Olds Ferry-Izee, Baker, and Wallowa terranes and in other terranes of the western US Cordillera (fig. 12; e.g., Wright and Fahan 1988; Hacker et al. 1995; Walker 1995; Irwin and Wooden 2001; Irwin 2003; Payne and Northrup 2003; Day and Bickford 2004; Allen and Barnes 2006; Unruh et al. 2008; Tumpane 2010; Northrup et al. 2011; Schwartz et al. 2011a, 2011b; Barth et al. 2012). The record of Jurassic magmatism in the BMP, both detrital and magmatic, is analogous to widespread concurrent magmatism in other terranes of the western US Cordillera.

Our two detrital zircon samples from the chertrich upper flysch unit at the type locality (07024) and chert-poor volcaniclastic sandstone near the top of the fluvial unit at Pittsburg Landing (07005) contain a very similar age distribution (fig. 10B, $10 C)$. The large contribution of volcanic cover rock ages suggests a continued Wallowa terrane source area during transgressive sedimentation. In both samples, the dominance of syndepositional grain ages of ca. 160-150 Ma suggests that an active magmatic arc source also contributed to sediment provenance. Finally, our sample from the youngest beds in the CHF at Pittsburg Landing (sample 13NM064B; fig. 10E) includes a large proportion of Wallowa terrane arc basement and volcanic cover rock ages. Again, a large number of syndepositional grain ages suggests input from and proximity to active magmatic arc sources during deposition.

In all of our CHF samples, detrital zircon ages close to the depositional age are consistent with a magmatically active convergent plate margin setting, and zircon ages reflecting arc basement and volcanic cover rock are consistent with an extensional back-arc or intra-arc setting (Cawood et al. 2012). Our samples do not include Archean, Proterozoic, or early Paleozoic detrital zircon grains and thus do not reflect recycling of older Baker or Izee terrane rocks, as would be expected during a Late Jurassic arc-arc collision (cf. Dickinson 1979, 2004; Avé Lallemant 1995; Schwartz et al. 2010, 2011a, $2011 b, 2014)$.

The $\epsilon_{\mathrm{Nd}}$ values ranging from $\sim 2$ at ca. $160 \mathrm{Ma}$ to $\sim 5$ at ca. $150 \mathrm{Ma}$ (fig. 11) are interpreted to record the increased input of juvenile arc detritus during Late Jurassic time, consistent with detrital zircon age distributions dominated by Permian-Triassic and Middle-Late Jurassic ages (i.e., young arc detritus and no Precambrian ages). 


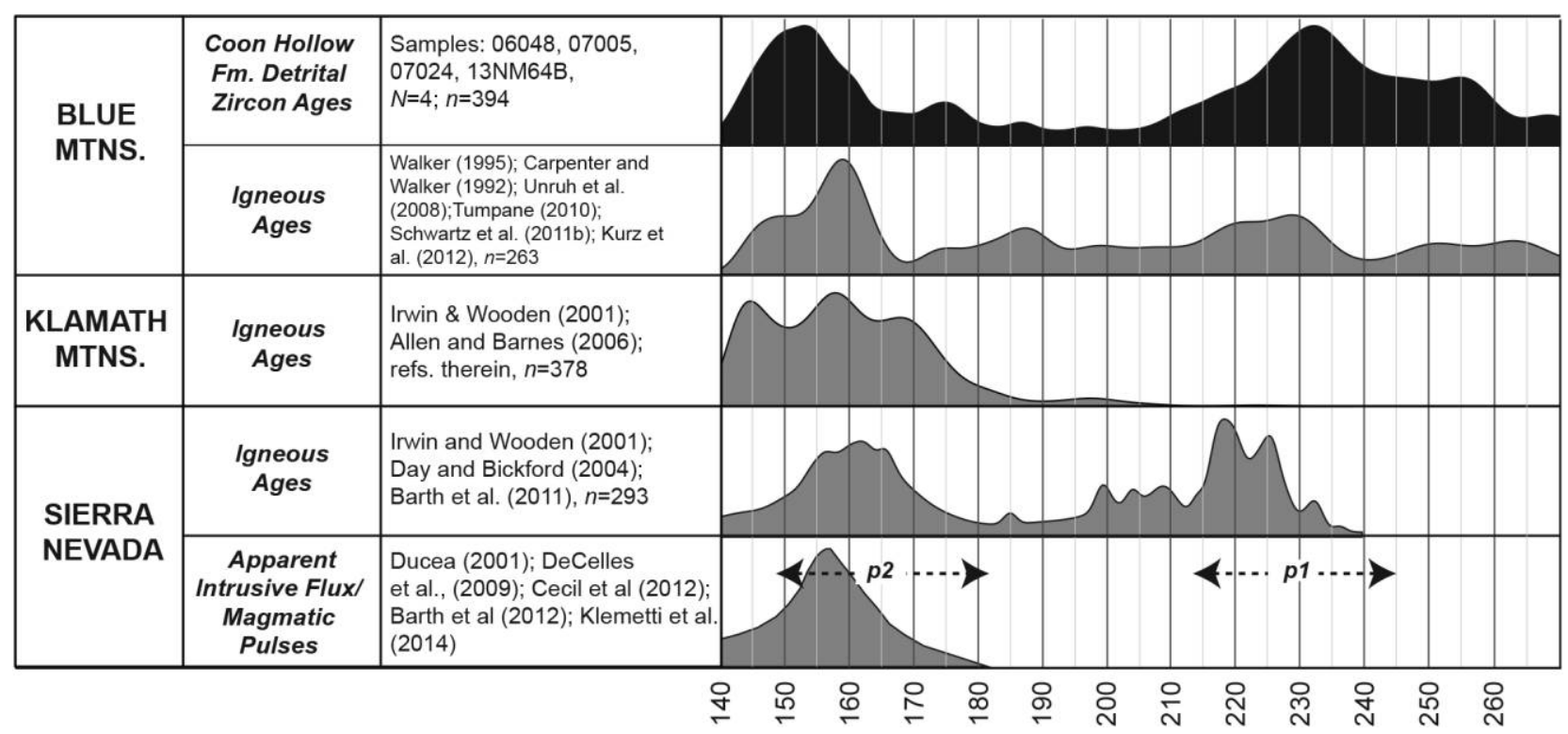

Figure 12. Comparison of Coon Hollow Formation detrital zircon ages to possible source areas in the Blue Mountains, Klamath Mountains, and Sierra Nevada. The probability distributions for igneous ages from the Blue Mountains, Klamath Mountains, and Sierra Nevada represent the likely distribution of ages that would be resolved using the laser ablation inductively coupled plasma mass spectrometry (LA-ICP-MS) method in a detrital sample representing each source area. These probability distributions were created by first compiling each of the ${ }^{206} \mathrm{~Pb}^{/ 238} \mathrm{U}$ ages that were reported from individual intrusive bodies in the cited publications. Then an error estimate of $3.6 \%(2 \sigma$; the mean error in our LA-ICP-MS analyses) was applied to each of these ages to render a probability distribution that is representative of that which might be expected were they measured in a detrital sample eroded from a pluton. Note that by design this method includes grains that may have been excluded from the final interpreted age in the cited publications; those analyses would not be excluded in a representative detrital sample. Magmatic pulses of the Sierra Nevada are represented by $\mathrm{p} 1$ and $\mathrm{p} 2$ (Barth et al. 2012).

Regional Implications. Both of our new Early Jurassic ages for the red tuff unit are considerably older ( 25 m.yr.) than previous Middle Jurassic estimates that were based on stratigraphic position beneath Middle Jurassic (Bajocian) corals (Stanley and Beauvis 1990; White et al. 1992; White 1994; White and Vallier 1994; Schmidt et al. 2009). Recognition of an Early Jurassic depositional age for the red tuff unit requires that red tuff magmatism in the Wallowa terrane is neither Middle Jurassic nor associated with deposition of the CHF. Rather, red tuff magmatism is coeval with deposition of the upper portions of the Hurwal Formation (fig. 4; Schmidt et al. 2009), and deposition of the red tuff unit is best considered in the context of crustal processes that formed the basin in which the Hurwal Formation was deposited.

Dorsey and LaMaskin $(2007,2008)$ suggested that Hurwal Formation deposition is related to flexural subsidence caused by a Molucca Sea-type arc-arc collision during Late Triassic-Early Jurassic time in the greater Blue Mountains region. In this model, structural interaction and deformation of the facing accretionary wedges of the Wallowa and Olds Ferry arcs resulted in crustal thickening, uplift, and growth of a doubly vergent thrust belt in the Baker terrane subduction complex that propagated into and disrupted the flanking forearc basins. Subsequent deepmarine deposition of the Hurwal Formation records migration of a flexural foredeep basin northwestward across the region (present coordinates). Fluvial conditions during this same time at Pittsburg Landing indicate differential subsidence in the Blue Mountains region with significant areas both above sea level and under deep-marine conditions in Early Jurassic time. These observations are consistent with an interpretation of Late Triassic-Early Jurassic crustal thickening and associated lithospheric flexure in the region during arc-arc collision (see Dorsey and LaMaskin 2007; LaMaskin et al. 2011b). We suggest that the angular unconformity between Middle Triassic through Early Jurassic volcanic rocks and the overlying CHF records tilting and erosion in the Wallowa terrane that we infer resulted from a Late Triassic-Early Jurassic offshore arc amalgamation event.

These new ages from the red tuff at Pittsburg Landing indicate that magmatism was active in the 
Wallowa terrane during Early Jurassic time (Tumpane 2010; Northrup et al. 2011). Early Jurassic magmatism in the interval ca. $200-180 \mathrm{Ma}$ is also well represented in rocks of the Olds Ferry and Izee terranes in eastern Oregon (LaMaskin et al. 2011b). In the Huntington, Oregon, region, rocks of the informal Jett Creek member of the Weatherby Formation contain abundant Early Jurassic detrital zircon grains and lack Precambrian ages (fig. 13). In the John Day region, sandstone in the Keller Creek shale is characterized by a single major distribution of Late Triassic-Early Jurassic grains (ca. 218-181 Ma; peak at $195 \mathrm{Ma}$ ) with a low percentage of Mesoproterozoic and Paleoproterozoic grains (LaMaskin et al. 2011b). We consider the concurrent Early Jurassic magmatism in both the Wallowa and the Olds Ferry-Izee terrane to further signify a link between Blue Mountain lithotectonic assemblages by Late Triassic-Early Jurassic time (see Tumpane 2010).

Our new data also demonstrate that the CHF is not correlative with Middle Jurassic sedimentary rocks in the John Day, Oregon, region, as proposed in previous studies (fig. 14; Pessagno and Blome 1986; White et al. 1992; Vallier 1995; Dickinson 2004, 2008; Dorsey and LaMaskin 2007, 2008; LaMaskin et al. 2008a). In addition to the depositional age difference, the CHF and Middle Jurassic deposits of the John Day region contain dissimilar detrital zircon age distributions (fig. 14). Thus, tec-

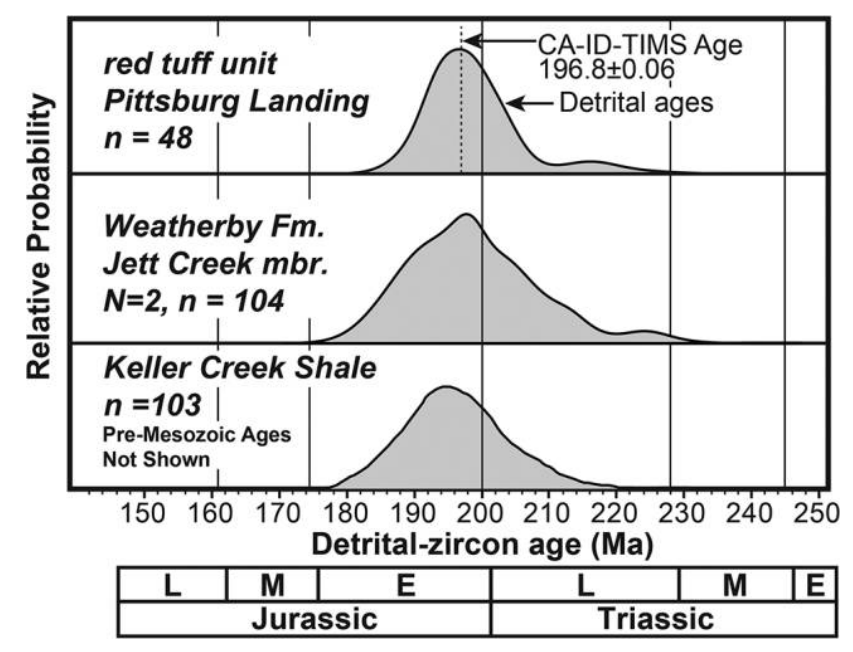

Figure 13. Illustration comparing U-Pb detrital zircon ages from the Keller Creek shale (John Day region) and Weatherby Formation (Huntington, OR, region) to the chemical abrasion isotope dilution thermal ionization mass spectrometry (CA-ID-TIMS) and laser ablation inductively coupled plasma mass spectrometry ages of the red tuff unit at Pittsburg Landing. tonic models for the evolution of the BMP that assume a regional Middle Jurassic overlap assemblage must be revised in light of this finding. Furthermore, the term "Izee basin" (Smith et al. 1980; LaMaskin et al. 2009; Schwartz et al. 2011b) should not include the $\mathrm{CHF}$; the term should be restricted to megasequence 2 Early and Middle Jurassic sedimentary rocks, including the Mowich Group and the Snowshoe, Trowbridge, and Lonesome Formations in the John Day region and the Weatherby Formation in the Huntington, Oregon, region (see also Dennet Creek limestone and Bill Hill shale in Payne and Northrup 2003).

The pronounced scarcity of pre-late Paleozoic grains in our CHF samples $13 \%$ of all grains were older than $260 \mathrm{Ma}$ ) contrasts sharply with data from Late Permian through Middle Jurassic deposits in the more inboard terranes of the Blue Mountains, which contain abundant early to midPaleozoic, Proterozoic, and Archean grains (Alexander and Schwartz 2009; LaMaskin et al. 2011b). This could be interpreted to mean that (1) the Wallowa terrane portion of the BMP was situated in an offshore oceanic setting ca. 160-150 Ma during Coon Hollow sedimentation or (2) despite a previous link to a source of older grains, BMP depocenters became isolated from cratonal and/or recycled sources by Late Jurassic time (ca. $160 \mathrm{Ma}$ ). Comparison of our data to regional western US data leads us to prefer scenario 2 (see below).

Deposition of the CHF ca. 160-150 Ma indicates that these strata are coeval with other well-studied Late Jurassic basins of the western United States; thus, our sedimentary provenance data are best interpreted through comparison with observations from other western US locations (fig. 15). Numerous authors have recognized a discontinuous belt of Jurassic-Cretaceous clastic turbiditic strata in the western United States. Broadly, these locations include two distinct depositional intervals, the oldest of which occurred during Late Jurassic time from the Middle Oxfordian to the end of the Tithonian stage ( 160 to $145 \pm 1$; Cowan and Brandon 1981; Garver 1988; McClelland et al. 1992; Miller and Saleeby 1995; Pessagno 2006). This Late Jurassic interval includes the Mariposa and Galice Formations in the Sierra Nevada and Klamath Mountains, respectively; the Ingalls graywacke in the northwestern Cascades; and rocks of the Fidalgo Complex, Lummi Formation, Constitution Formation, and Easton Metamorphic Suite in the San Juan Islands of Washington.

Below, we briefly review the age, lithology, and provenance of these western US basins for comparison to our new data from the CHF. The Mariposa 


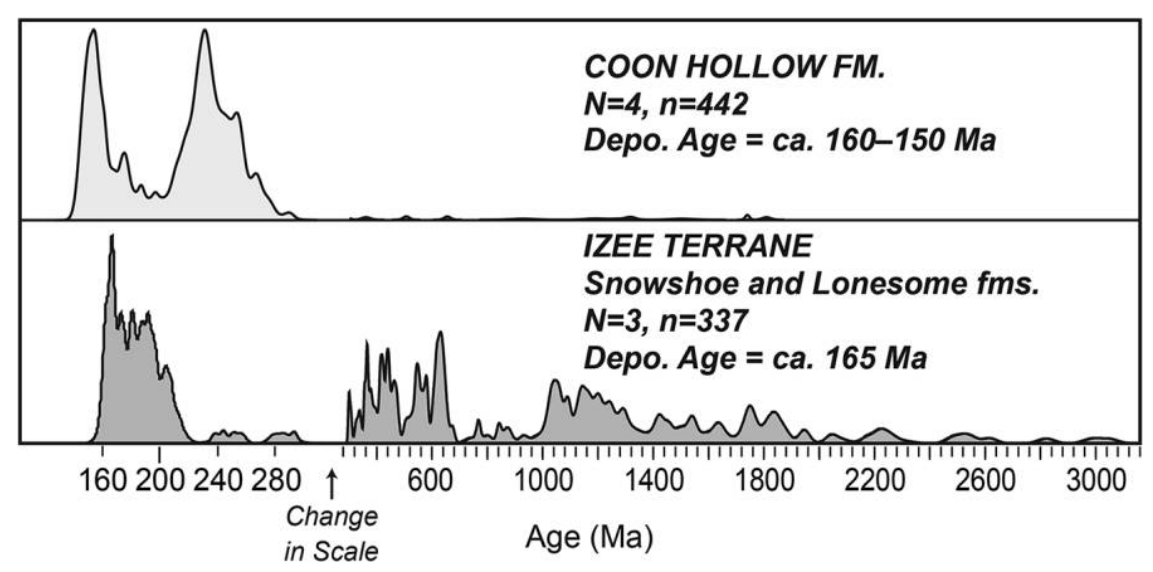

Figure 14. U-Pb detrital zircon ages from the Coon Hollow Formation and from Middle Jurassic rocks of the John Day region illustrating a lack of provenance affinity between the two sample sets. A color version of this figure is available online.

Formation crops out in a 250-km-long, north-southtrending belt in the western foothills of the southern Sierra Nevada (fig. 15; Saleeby 1982; Bogen 1984; Snow and Ernst 2008; Ernst et al. 2009). The Mariposa Formation was deposited on the Late TriassicEarly Jurassic Peñon Blanco arc, proximal to North America (Bogen 1984; Snow 2007; Snow and Ernst 2008). Accumulation of the Mariposa Formation began no later than ca. $160 \mathrm{Ma}$ and ended ca. $153 \mathrm{Ma}$, as shown by a SIMS U-Pb zircon age from a hypabyssal intrusive that crosscuts and metamorphoses the unit (Ernst et al. 2009). These thick-bedded deep-marine turbidites have undergone severe internal deformation attributed to the Nevadan orogeny (sensu stricto; syndepositional structural compression ca. $155 \pm 5$ Ma; Snoke 1977; Saleeby et al. 1982; Harper and Wright 1984; Schweickert et al. 1984, 1999; Wyld and Wright 1988; Tobisch et al. 1989; Harper et al. 1994; Hacker et al. 1995; Snow 2007; Dickinson 2008). While some have argued for Late Jurassic collision of an exotic arc as a mechanism for the Nevadan orogeny (e.g., Moores 1970; Schweickert and Cowan 1975; Day et al. 1985; Ingersoll and Schwieckert 1986; Moores et al. 2002), many workers now agree that the Nevadan orogeny (sensu stricto) was noncollisional, affected only suprasubduction-zone rocks, and resulted from subduction of a seafloor spreading center (e.g., Shervais et al. 2005) or changes in convergence rate and direction of subducting lithosphere (e.g., Wright and Fahan 1988; Ernst 1990; Hacker et al. 1993, 1995; Harper et al. 1994). Detrital zircon grains from the Mariposa Formation represent 60\% Mesozoic ages (ca. 175-160 Ma), with lesser Paleozoic, Proterozoic, and Archean ages interpreted as a transcontinental Ouachita-Appalachian provenance enriched by southwestern US and active early Mesozoic Cordilleran arc sources (LaMaskin 2012) or as derived from the eastern Klamath terranes, the Paleozoic miogeocline of Nevada, and the Sierra Nevada arc (Snow and Ernst 2008).

The Galice Formation is an Upper Jurassic sedimentary succession (fig. 15; ca. 157-150 Ma) in the western Klamath terrane of the Klamath Mountains, Oregon and California (Snoke 1977; Harper 1984; Wyld 1985; Wyld and Wright 1988; Harper et al. 1994; Frost et al. 2006; MacDonald et al. 2006; Pessagno 2006). Numerous studies document a trend of increasing chert grains with stratigraphic height in the Galice Formation (Harper 1980; Norman 1984; Wyld 1985; Wyld and Wright 1988; MacDonald et al. 2006). While some debate regarding collision of exotic terranes continues (e.g., Schwieckert and Cowan 1975; Moores et al. 2002), many workers agree that the Galice basin formed as a result of intra-arc extension of a west-facing Middle Jurassic arc, which resulted in formation of the ca. 164-162 Ma Josephine ophiolite, leaving portions of the remnant Middle Jurassic arc stranded to the east (Snoke 1977; Saleeby et al. 1982; Harper and Wright 1984; Wyld and Wright 1988; Harper et al. 1994; Hacker et al. 1995; Yule et al. 2006, 2009). The Galice succession overlies and is genetically related to both the ca. 160$157 \mathrm{Ma}$ Rogue-Chetco arc complex and the Josephine ophiolite. At the end of deposition, the Galice basin was structurally compressed and overthrust by older terranes of the Klamath Mountains during the Late Jurassic Nevadan orogeny (sensu stricto; Snoke 1977; Saleeby et al. 1982; Harper and Wright 1984; Hacker et al. 1995). Detrital zircon ages from the Galice Formation represent a bimodal age distribution of ca. 153 and 227 Ma grains with a minor Protero- 


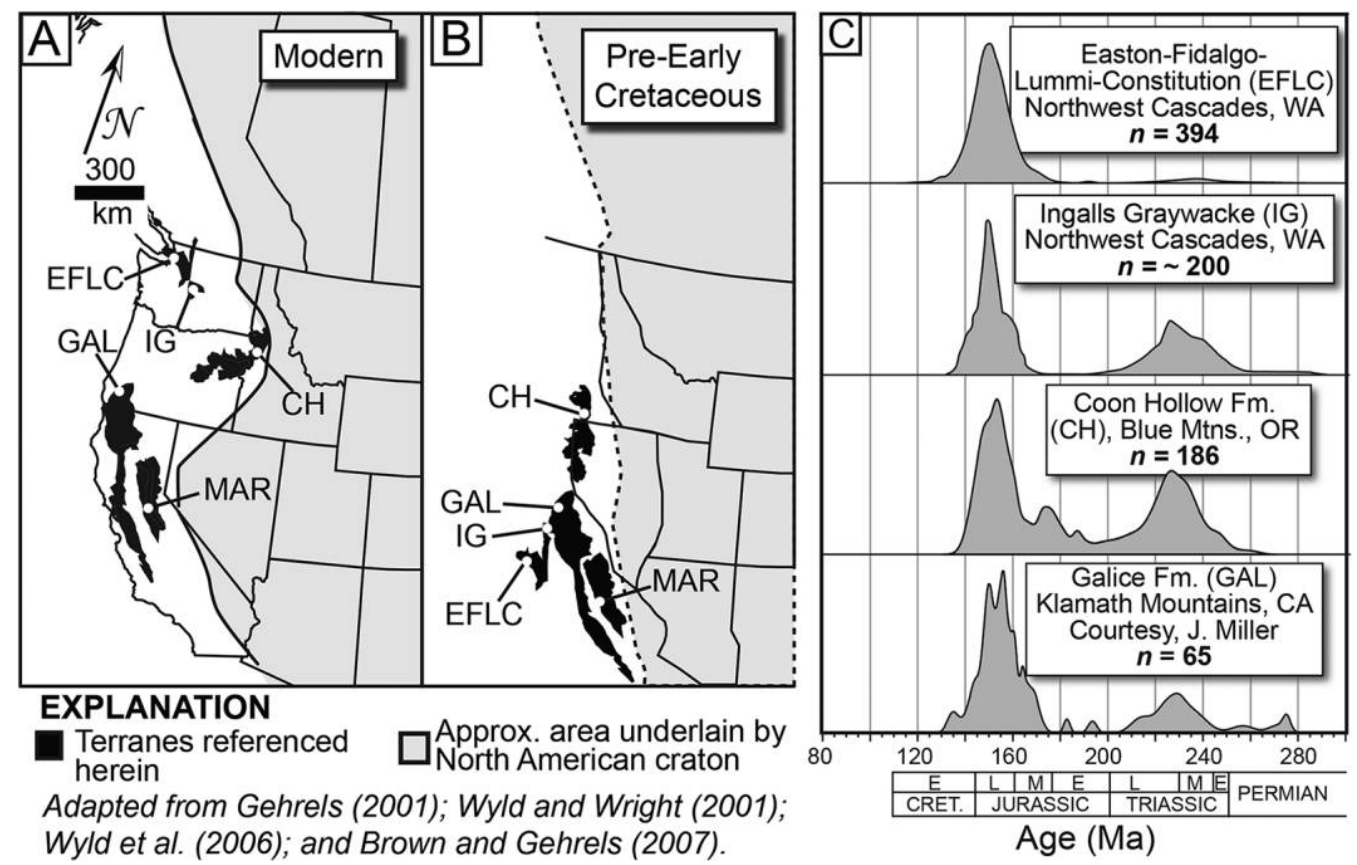

Figure 15. Modern $(A)$ and pre-Early Cretaceous $(B)$ distribution of selected Late Jurassic-Early Cretaceous basins and their detrital zircon age distributions $(C)$. $\mathrm{CH}=$ Coon Hollow Formation; EFLC = Easton-Fidalgo-LummiConstitution; GAL = Galice Formation; $\mathrm{IG}=$ Ingalls graywacke.

zoic component (Miller et al. 2003; MacDonald et al. 2006).

Currently located north of the Blue Mountains, the Ingalls ophiolite-graywacke complex is exposed in the northwestern Cascades province of Washington and represents a northern equivalent of the Josephine ophiolite of California and Oregon, offset to its current location by dextral plate-boundary fault offset (fig. 15; e.g., Brown and Blake 1987; Garver 1988; Saleeby 1992; Metzger et al. 2002; Miller et al. 2003; Wyld et al. 2006; LaMaskin 2012). The upper portions of the sedimentary succession are poorly dated as Late Jurassic, Oxfordian-Kimmeridgian in age. Chert-rich lithic wacke yields a bimodal detrital zircon age distribution with modes ca. 153 and $223 \mathrm{Ma}$ (Harper et al. 2003).

Finally, in the San Juan Islands of Washington, rocks of the Fidalgo Complex, Lummi Formation, Constitution Formation, and Easton Metamorphic Suite are related to one another and have been interpreted to represent marginal basins that are correlative with terranes in the western Klamath Mountains (fig. 15; Galice Formation; Saleeby and BusbySpera 1992; Anderson and Mahoney 2006; Brown and Gehrels 2007). These units include chert-rich lithic wacke, and each bears detrital zircons with a prominent age mode ca. 155-148 Ma and minor Late Triassic ages (Brown and Gehrels 2007).
Rocks of the Galice Formation (and the offset Ingalls ophiolite-graywacke complex), as well as the correlative Mariposa Formation, have long been recognized as deposits of marginal basins that evolved proximal to the North American continent, bearing xenocrystic zircon, Precambrian detrital zircon, and negative $\epsilon_{\mathrm{Nd}}$ values in whole-rock argillite samples (fig. 11; Armstrong and Dick 1974; Snoke 1977; Harper 1980, 1984; Saleeby et al. 1982; Harper and Wright 1984; Wright and Wyld 1986; Hacker and Ernst 1993; Miller and Saleeby 1995; Frost et al. 2006; MacDonald et al. 2006; Snow and Scherer 2006; Yule et al. 2006; Snow and Ernst 2008; LaMaskin 2012). Each of these units except the Mariposa Formation contains an increasing chert-grain component with stratigraphic height and detrital zircon age distributions that are essentially identical, with abundant Middle-Late Jurassic ages, lesser amounts of Triassic ages, and a low number of Precambrian ages (fig. 15C).

Age, lithology, and provenance data show that the CHF, Galice Formation, Ingalls graywacke, Fidalgo Complex, Lummi and Constitution Formations, and Easton Metamorphic Suite all represent dismembered remnants of a Late Jurassic marginal basin system on the western US plate margin and support the paleogeographic reconstructions of Wyld and Wright (2001) and Wyld et al. (2006). The coeval Mariposa basin, in the southern Sierra Ne- 
vada, bears a dissimilar provenance that represents sediment derivation from a largely Middle Jurassic magmatic arc (ca. 175-160 Ma ages) as well as from previously collided arcs or continental sources during Late Jurassic time (Snow and Ernst 2008; LaMaskin 2012). This is consistent with the southward position of the Mariposa Formation (fig. 15B) and suggests that a broad area of suprasubduction extension acted to isolate the Klamath and Blue Mountain regions from cratonal sources of sandsized detritus, while the Mariposa basin maintained an active sedimentary connection to the North American craton.

Timing of Wallowa Terrane Accretion and Deformation. Deposition of the CHF occurred proximal to western North America beginning in Middle Oxfordian time, ca. $160 \mathrm{Ma}$ (early Late Jurassic). The 37-m.yr. hiatus between deposition of the Pittsburg Landing red tuff unit and the CHF spans the period when the Wallowa terrane was accreted to western North America (197-160 Ma). Beneath this unconformity, Wallowa terrane sedimentary and igneous rocks show an intraoceanic character in detrital zircon ages, Sm-Nd isotopic values, and trace element geochemistry (LaMaskin et al. 2008a, 2008b; Kurz et al. 2011; this study). Above the unconformity, ca. 160-150 Ma rocks of the CHF bear clear ties in age, lithology, and provenance to rocks of western North American affinity.

Accretion of the outboard Wallowa terrane prior to $160 \mathrm{Ma}$ is consistent with pre-Late Jurassic accretion in all major Paleozoic-Mesozoic terranes of the western United States. In the Klamath Mountains, widespread Middle Jurassic plutons of the Wooley Creek suite stitch previously accreted preLate Jurassic terranes and indicate that any ocean basin that lay between the western US plate margin and offshore Triassic-Jurassic island arcs had closed by the end of Middle Jurassic time (e.g., Wright and Fahan 1988; Hacker and Ernst 1993; Hacker et al. 1993; Wright and Wyld 1994; Allen and Barnes 2006; Barnes et al. 2006; Dickinson 2008; Ernst et al. 2008; Ernst 2015). Although accretion timing may be more ambiguous in the Sierra Nevada on the basis of the ages of stitching plutons (see the review in Dickinson 2008), numerous interpretations suggest that accretion was complete by the end of Middle Jurassic time (e.g., Dilek et al. 1988; Sharp 1988; Dilek 1989; Edelman and Sharp 1989; Herzig and Sharp 1992; Girty et al. 1995; Miller and Saleeby 1995; Godfrey and Dilek 2000; Snow and Scherer 2006; Snow 2007). In particular, the most outboard Sierran terrane, the Western belt, is interpreted to have been sutured to North America specifically by ca. $160 \mathrm{Ma}$ (Day and Bickford 2004). Accretion of the Wallowa terrane (and the previously amalgamated BMP) was part of pre-Late Jurassic regional accretion recorded throughout the western United States.

Prior interpretations of initial BMP terrane accretion at $\sim 18 \mathrm{Ma}$ (Lund and Snee 1988) and 135$130 \mathrm{Ma}$ (Fleck and Criss 1985; Criss and Fleck 1987; Snee et al. 2007) are based on ${ }^{40} \mathrm{Ar} /{ }^{39} \mathrm{Ar}$ ages in hornblende and biotite in the Salmon River belt and likely represent metamorphic cooling ages (see Selverstone et al. 1992). They do not constrain the timing of terrane accretion but instead record stages in the metamorphic evolution of the Salmon River fold-thrust belt during Sevier-age crustal deformation and orogenesis. In our interpretation, garnet core zones that permit an early metamorphic event at 144-136 Ma (Getty et al. 1993) represent postcollisional events associated with growth and early evolution of the nascent western US ocean-continent subduction system.

Arc-continent collision is not recorded by penetrative deformation in exposed rocks of the Wallowa terrane, which were in a supracrustal, fluvialto deep-marine setting during accretion or in rocks of the adjacent Salmon River belt, which have been strongly altered by subsequent magmatism, thrusting, and dextral shear. Analysis of BMP data in a regional context suggests that pre-Late Jurassic accretion of terranes by back-arc closure is recorded in rocks of northern Nevada (Black Rock terrane and Auld Lang Syne Group), and rocks of the BMP were subsequently translated $\sim 400 \mathrm{~km}$ north during Late Cretaceous time (e.g., Oldow 1984; Wyld and Wright 2001; Wyld 2002; Wyld et al. 2003, 2006; Dorsey and LaMaskin 2007; LaMaskin et al. 2011a).

Gray and Oldow (2005) recognized the preCretaceous accretion of the Wallowa terrane but suggested that the earliest deformation of Wallowa terrane rocks (interpreted to include the $\mathrm{CHF}$ ) occurred between ca. $157 \mathrm{Ma}$ (i.e., post-Oxfordian) and ca. 145 $\mathrm{Ma}$. In contrast, we find that pre-Late Jurassic deformation of the Wallowa terrane is recorded by the regional angular unconformity beneath the $\mathrm{CHF}$ and that this regional deformation occurred between ca. 197 and $160 \mathrm{Ma}$. The most conservative interpretation of our detrital zircon data requires that deformation of the CHF into broad-to-tight, opento-overturned folds (see Schmidt et al. 2009) occurred after $148 \pm 1 \mathrm{Ma}$ (Tithonian; oldest maximum depositional age estimate from our youngest sample). Using the age constraints of Gray and Oldow (2005), postaccretion deformation may have occurred during a brief interval ca. 148-145 Ma, consistent with garnet growth ages in the adjacent Salmon River belt (Getty et al. 1993). We also note that deformation may have been continuous with 
CHF deposition ca. 160-150 Ma. Schmidt et al. (2009) note extreme southward thickening of the $\mathrm{CHF}$, and we suggest that syndepositional deformation of the CHF may represent inboard deformation during closure of Late Jurassic suprasubduction basins.

Implications for Western US Plate Margin Evolution. The nature of the plate interactions that controlled the development of the western US plate margin from Permian to Cretaceous time has been the subject of much debate over decades of research. In the Sierra Nevada and Klamath Mountains, numerous authors recognize a major change in plate margin dynamics from a series of multiple trenches, microplates, fringing arcs, and basins in Early-Middle Jurassic time to a single-trench, east-dipping subduction system sometime in the Late Jurassic-Early Cretaceous periods, signaling the onset of an integrated, Andean-type geodynamic system (e.g., Monger and Price 1979; Jordan 1981; Harper and Wright 1984; Oldow et al. 1989; Burchfiel et al. 1992; Wright and Fahan 1988; Saleeby and Busby-Spera 1992; Coney and Evenchick 1994; Dickinson et al. 1996; DeCelles 2004; Ernst 2012; many others). However, apparent differences in the Late Jurassic geology between the Sierra Nevada, Klamath Mountains, and Blue Mountains have prevented development of a unified model for plate margin development. Recognition that the CHF formed in a Late Jurassic suprasubduction extension-related marginal basin directly ties the BMP to the Klamath Mountains during the time 160-150 Ma and fills a critical gap in our knowledge of plate interactions that controlled the development of the western US plate margin.

By 165-160 Ma, arc accretion had ended in all major terranes of the western United States (Harper and Wright 1984; Coleman et al. 1988; Wright and Fahan 1988; Hacker et al. 1995; Barnes et al. 2006; Dorsey and LaMaskin 2007), and a period of postaccretionary subduction and extensional trench retreat began ca. 160-155 Ma (fig. 16), when subduction along the western margin of the Klamath belts may have permitted plate convergence to continue following closure of the former back-arc region to the east and north (cf. the section titled "Backarc Geodynamics" in Dickinson 2006, p. 360-362). Upper-plate extension rifted the Rogue-Chetco arc away from the Laurentian margin, forming the Jo-

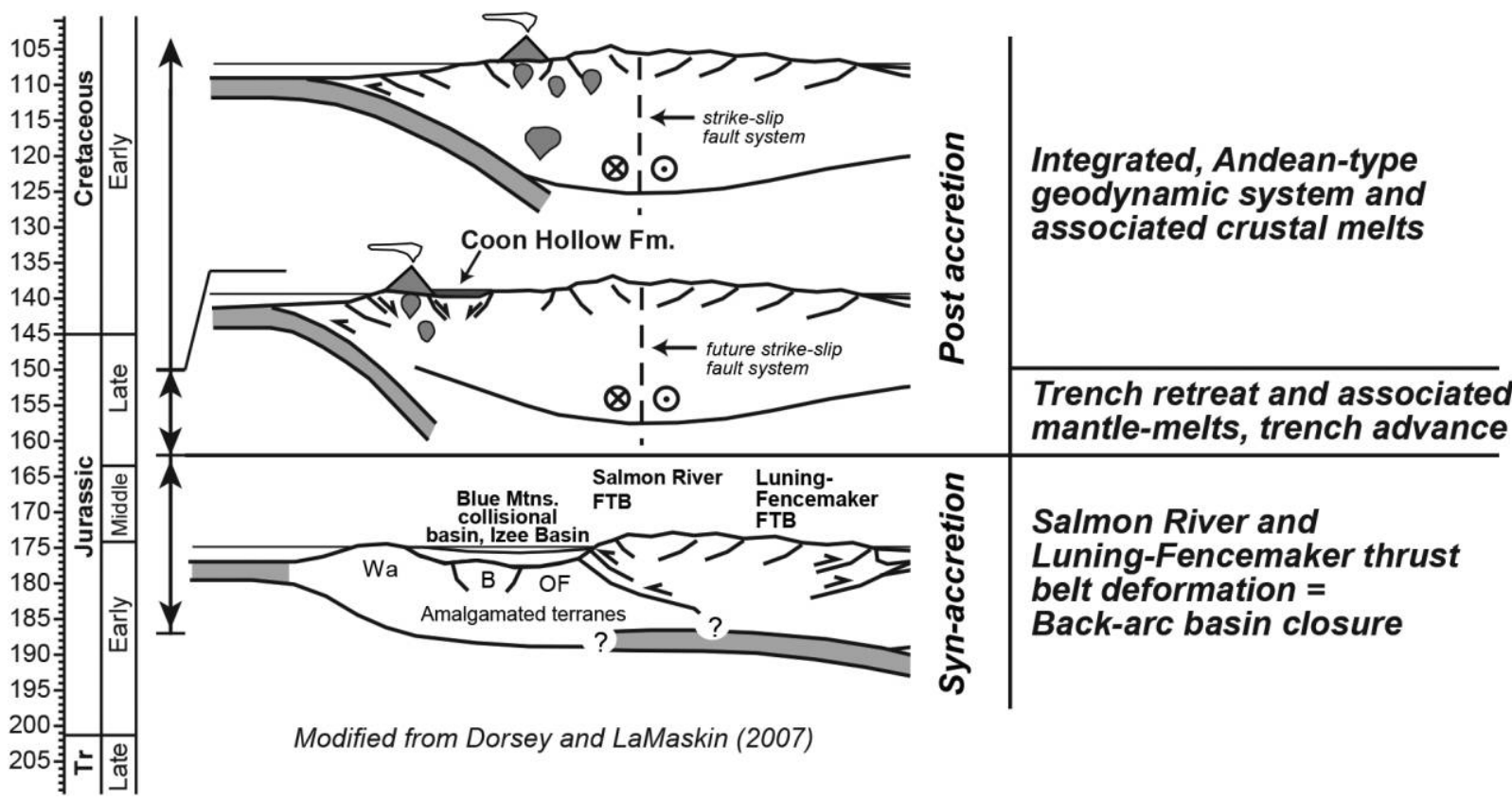

Figure 16. New model for Jurassic tectonic setting and evolution of the Blue Mountains province (BMP). EarlyMiddle Jurassic accretion of the previously collided BMP terranes to the western North American margin was accomplished by closure of a marginal basin. Postaccretion tectonics include an early phase ca. 160-150 of trench retreat and associated mantle-derived magmatism, followed by trench advance and subsequent formation of an integrated, Andean-type geodynamic system (modified from Dorsey and LaMaskin 2007, 2008; LaMaskin et al. $2008 a$, 2011a, 2011b; LaMaskin 2012). B = Baker terrane; FTB = fold-thrust belt; OF = Olds Ferry terrane; Wa = Wallowa terrane. 
sephine ophiolite and overlying marine Galice Formation in the Klamath Mountains as well as the coeval Smartville ophiolite in the Sierra Nevada.

In the Blue Mountains, the Late Jurassic period of trench retreat is recorded by the lower $\mathrm{CHF}$, and a remnant arc is represented by the Olds FerryIzee arc stranded to the east (fig. 16). In contrast to the Klamath Mountains and the Sierra Nevada, the Blue Mountains lack a Late Jurassic ophiolite succession, and the CHF does not show evidence for Late Jurassic penetrative deformation, as is seen in the Galice Formation. We do note that Late Jurassic deformation is widely recognized in other parts of the Blue Mountains (e.g., Avé Lallemant 1995; Schwartz et al. 2010, 2011a, 2011b), and deformation may have been continuous with CHF deposition. We propose that suprasubduction extension was less pronounced in the north than in more southerly locations and that the Coon Hollow basin may have occupied a more inboard location than the Galice-Ingalls basin. As a result, the Blue Mountains lack a Late Jurassic ophiolite, and the CHF was not penetratively affected by outboard Nevadan deformation.

In this scenario, mantle-derived plutons ca. 162 $157 \mathrm{Ma}$ in the Blue Mountains (Schwartz et al. 2011a, 2014) and the Klamath Mountains (Allen and Barnes 2006; Barnes et al. 2006) were emplaced during the
Late Jurassic retreating phase, stitching the previous late Middle Jurassic deformation (Saleeby et al. 1992; Barth et al. 2012). Trench retreat was closely followed by trench advance during the Nevadan orogeny (sensu stricto), which resulted in closure of suprasubduction zone extensional back-arc basins and the cessation of sedimentation in the Blue Mountains. Initiation of the Great Valley forearc ca. $150 \mathrm{Ma}$ in central California and southeastern Oregon suggests that a coherent forearc was established by early Late Jurassic time immediately following the Nevadan orogeny (sensu stricto; Ingersoll 1983; Surpless et al. 2006; Wright and Wyld 2006). Subsequent crustal melts ca. 150-145 Ma in the Blue Mountains (Schwartz et al. 2011a, 2014) and the Klamath Mountains (Allen and Barnes 2006; Barnes et al. 2006) represent crustal thickening associated with development of the nascent, integrated, Andean-type geodynamic system (fig. 16).

As shown by LaMaskin (2012), numerous terrane assemblages of the western United States record this succession of tectonomagmatic events in sedimentary provenance, but recognition of the $\mathrm{CHF}$ as correlative to the Galice Formation requires a reinterpretation of the tectonic controls on sediment provenance (fig. 17). Early-Middle Jurassic sediments were derived from both craton and plate margin arc sources and were deposited in basins

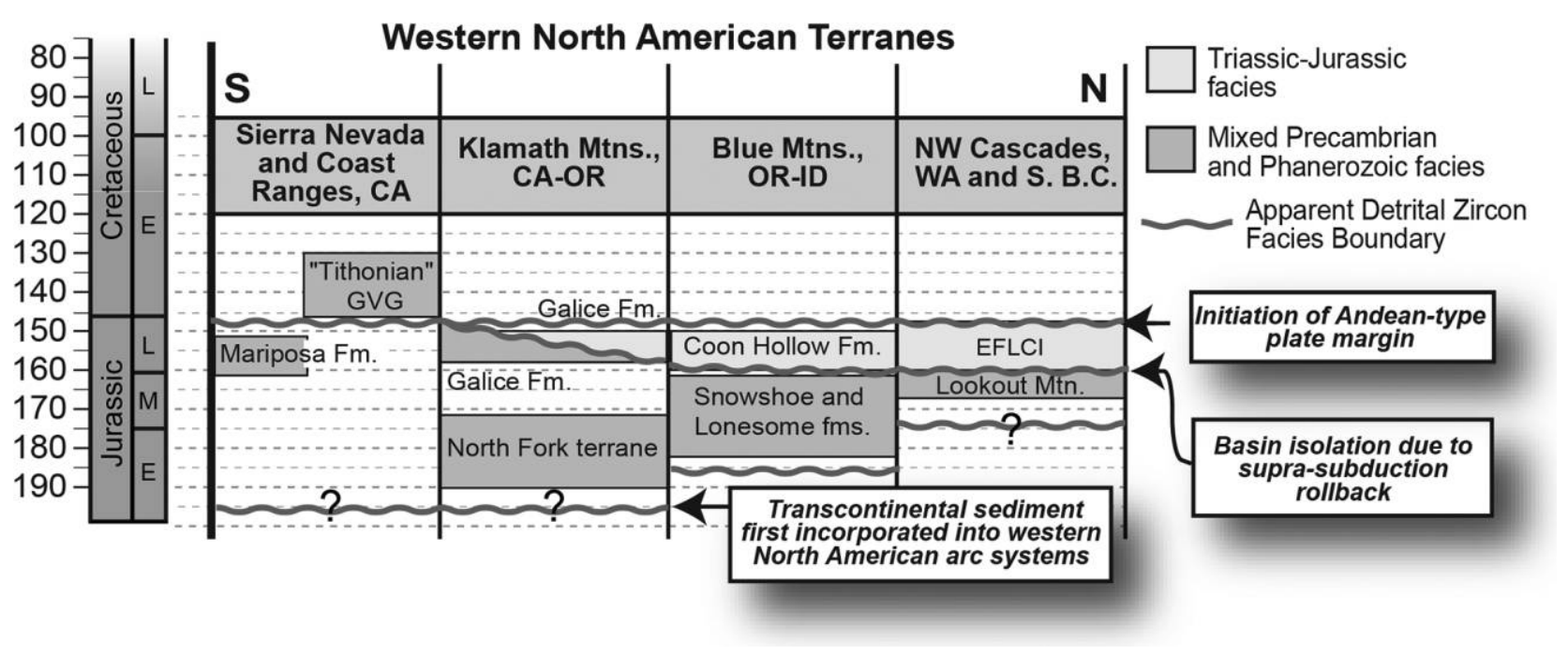

Figure 17. Chronostratigraphic distribution of Jurassic and earliest Cretaceous detrital zircon facies in western North American terranes (modified from LaMaskin 2012). The presence of Triassic-Jurassic facies defined by a dominant Middle-Late Jurassic (ca. 175-145 Ma) age distribution, with variable quantities of Triassic (ca. 250-220 Ma) and a general lack of Precambrian ages, is here interpreted to represent basin isolation due to slab rollback and formation of suprasubduction zone basins represented by the Galice Formation, Coon Hollow Formation, Fidalgo Complex, Lummi Formation, Constitution Formation, and Easton Metamorphic Suite. EFLCI = Easton-FidalgoLummi-Constitution; GVG = Great Valley Group. A color version of this figure is available online. 
associated with a marginal basin regime (i.e., mixed Precambrian and Phanerozoic facies; LaMaskin 2012). The Late Jurassic (ca. $160 \mathrm{Ma}$ ) provenance change to plate margin arc-only sources (i.e., TriassicJurassic facies; LaMaskin 2012) is interpreted here to record topographic isolation and sediment overwhelming of the suprasubduction zone GaliceIngalls-Coon Hollow basin along a rapidly retreating plate margin (cf. LaMaskin 2012). Latest Jurassic to early Cretaceous sediments of the Basal Great Valley Group record a ca. 150-145 Ma return to both craton-derived and plate margin arc sources during initial Farallon plate subduction along the nascent Andean-type margin. Subsequent massive growth of the Sierran magmatic arc ca. $120 \mathrm{Ma}$ isolated the forearc region from the craton, yielding a record of arc-region-derived sand (DeGraaff-Surpless et al. 2002; Barth et al. 2011). The integrated Andeantype geodynamic system underwent numerous cycles of advance and retreat (DeCelles et al. 2009) and lasted until ca. $20 \mathrm{Ma}$ with initiation of the San Andreas transcurrent regime due to Farallon spreading center subduction (Atwater 1970; Dickinson 2008).

\section{Summary and Conclusions}

The CHF is a regional Late Jurassic sedimentary overlap assemblage that is not correlative with Middle Jurassic rocks of the John Day region. The radioisotopic provenance of the CHF indicates derivation from a Late Jurassic juvenile arc system and is virtually identical to the provenance of numerous other basins of a similar age along the western US Cordillera. Recognition of a North American provenance in the CHF shows that the Wallowa terrane substrate was accreted to western North America by or before ca. $160 \mathrm{Ma}$. The accreted lithosphere and superposed marine basin were part of a long belt of regional Late Jurassic (ca. 160-150 Ma) postaccretionary basins that formed during a brief period of trench retreat and suprasubduction zone extension immediately prior to establishment of the integrated, Andean-type convergent margin.

Recognition of a North American source for Late Jurassic sedimentary rocks in the Blue Mountains provides a critical link between the allochthonous Wallowa terrane and western North America and between the Blue Mountains and the Klamath Mountains and Sierra Nevada. Our observations clarify the timing (pre-Late Jurassic; ca. $160 \mathrm{Ma}$ ) and the nature (postaccretion trench retreat and advance) of the complex transition from an Early-Middle Jurassic marginal basin system to a post-150 Ma, integrated, Andean-type convergent margin. In the Blue Mountains region, westward expansion of Laurentia was accomplished by pre-Late Jurassic accretion of previously amalgamated pericratonic and intraoceanic arc terranes. The similarity of Late Jurassic sedimentary rocks in the BMP to numerous other western US basins suggests a margin-wide response to changing tectonic boundary conditions in an evolving convergent-margin setting.

\section{A C K N O W LED G MENTS}

This study was supported by funds from the $\mathrm{Na}$ tional Science Foundation to R. J. Dorsey (EAR0537691) and J. D. Vervoort (EAR-0537913) and from the University of North Carolina Wilmington to T. A. LaMaskin. We thank D. Norfleet, L. O'Driscoll, A. Lutz, and C. J. Northrup for assistance in the field; C. Knaack, G. Hart, and V. Valencia for support with U-Pb laser ablation inductively coupled plasma mass spectrometry analyses; and D. Wilford and J. Donovan for assistance with sample preparation. Our ideas on the complex Mesozoic tectonics of the western United States benefited from many discussions with W. Dickinson, D. Cowan, J. MacDonald, B. Tikhoff, J. Schwartz, A. Snoke, and T. Vallier. T. A. LaMaskin especially appreciates instructive discussions with S. Wyld and J. Wright. We thank K. Surpless and R. Lewis, as well as the editorial staff, for constructive and thoughtful reviews.

\section{REFERENCES CITED}

Alexander, R. S., and Schwartz, J. J. 2009. Detrital zircon geochronology of Permian-Triassic metasedimentary rocks in the Baker terrane, Blue Mountains province, NE Oregon (abs.). Geol. Soc. Am. Abstr. Program 41:294.

Allen, C. M., and Barnes, C. G. 2006. Ages and some cryptic sources of Mesozoic plutonic rocks in the Klamath Mountains, California and Oregon. Geol.
Soc. Am. Spec. Pap. 410:223-245. doi:10.1130/2006 $.2410(11)$.

Anderson, B. S. 2013. Magmatism and deformation in the Mountain Home Metamorphic complex, Blue Mountains province, Oregon, and its role in Late Jurassic deformation in the western North American Cordillera. MS thesis, University of Alabama, Tuscaloosa. 
Anderson, T. H., and Mahoney, J. B. 2006. Late Jurassic basins: the tracks of a continental-scale transform from the Gulf of Mexico to Alaska. In Haggart, J. W.; Enkin, R. J.; and Monger, J. W. H., eds. Paleogeography of the North American Cordillera: evidence for and against large-scale displacements. Geol. Assoc. Can. Spec. Pap. 46:369-375.

Armstrong, R. L., and Dick, H. J. B. 1974. A model for the development of thin overthrust sheets of crystalline rock. Geology 2:35-40. doi:10.1130/0091-7613(1974) 2<35:AMFTDO $>2.0 . \mathrm{CO} ; 2$

Armstrong, R. L.; Taubeneck, W. H.; and Hales, P. O. 1977. Rb-Sr and K-Ar geochronometry of Mesozoic granitic rocks and their $\mathrm{Sr}$ isotopic composition, Oregon, Washington, and Idaho. Geol. Soc. Am. Bull. 88: 397-411.doi:10.1130/0016-7606(1977)88<397:RAKGOM $>2.0 . \mathrm{CO} ; 2$

Ash, S. R. 1991. A new Jurassic flora from the Wallowa terrane in Hells Canyon, Oregon and Idaho. Oregon Geol. 53:27-33.

Ash, S. R., and Pigg, K. B. 1991. A New Jurassic Isoetites (Isoetales) from the Wallowa terrane in Hells Canyon, Oregon and Idaho. Am. J. Bot. 78:1636-1642.

Atwater, T. 1970. Implications of plate tectonics for the Cenozoic tectonic evolution of western North America. Geol. Soc. Am. Bull. 81:3513-3536. doi:10.1130/0016 -7606(1970)81[3513:IOPTFT]2.0.CO;2.

Avé Lallemant, H. G. 1995. Pre-Cretaceous tectonic evolution of the Blue Mountains province, northeastern Oregon. In Vallier, T. L., and Brooks, H. C., eds. Geology of the Blue Mountains region of Oregon, Idaho, and Washington: petrology and tectonic evolution of pre-Tertiary rocks of the Blue Mountains region. U.S. Geol. Surv. Prof. Pap. 1438:271-304.

Barnes, C. G.; Snoke, A. W.; Harper, G. D.; Frost, C. D.; McFadden, R. R.; Bushey, J. C.; Barnes, M. A. W. 2006. Arc plutonism following regional thrusting: petrology and geochemistry of syn- and post-Nevadan plutons in the Siskiyou Mountains, Klamath Mountains province, California. Geol. Soc. Am. Spec. Pap. 410:357376. doi:10.1130/2006.2410(17).

Barth, A. P.; Walker, J. D.; Wooden, J. L.; Riggs, N. R.; and Schweickert, R. A. 2011. Birth of the Sierra Nevada magmatic arc: early Mesozoic plutonism and volcanism in the east-central Sierra Nevada of California. Geosphere 7:877-897. doi:10.1130/GES00661.1.

Barth, A. P.; Wooden, J. L.; Jacobson, C. E.; and Economos, R. V. 2012. Detrital zircon as a proxy for tracking the magmatic arc system: the California arc example. Geology 41:223-226. doi:10.1130/G33619.1.

Blake, D. E. 1991. Geology of the western Idaho suture zone in the Salmon River gorge, west-central Idaho. Ph.D. dissertation, Washington State University, Pullman.

Blake, D. E.; Gray, K. D.; Giorgis, S.; and Tikoff, B. 2009. A tectonic transect through the Salmon River suture zone along the Salmon River Canyon in the Riggins region of west-central Idaho. In $\mathrm{O}^{\prime}$ Connor, J. E.; Dorsey, R. J.; and Madin, I. P., eds. Volcanoes to vineyards: geologic field trips through the dynamic landscape of the
Pacific Northwest. Geol. Soc. Am. Field Guide 15:345372. doi:10.1130/2009.fld015(18).

Bogen, N. L. 1984. Stratigraphy and sedimentary petrology of the Upper Jurassic Mariposa Formation, western Sierra Nevada, California. In Crouch, J. K., and Bachman, S. B., eds. Tectonics and sedimentation along the California margin. Pub. 38. Los Angeles, Pac. Sect. Soc. Econ. Paleontol. Mineral., p. 119134.

Bouvier, A.; Vervoort, J. D.; and Patchett, P. J. 2008. The Lu-Hf and Sm-Nd isotopic composition of CHUR: constraints from unequilibrated chondrites and implications for the bulk composition of terrestrial planets. Earth Planet. Sci. Lett. 273:48-57.

Brooks, H. C. 1979. Geologic map of Huntington and part of Olds Ferry quadrangles, Oregon. Oregon Dept. Geol. Mineral Ind., Geologic Map Series, GMS-13, scale 1: 62,500.

Brown, E. H., and Blake, M. C. 1987. Correlation of Early Cretaceous blueschists in Washington, Oregon and northern California. Tectonics 6:795-806.

Brown, E. H., and Gehrels, G. E. 2007. Detrital zircon constraints on terrane ages and affinities and timing of orogenic events in the San Juan Islands and North Cascades, Washington. Can. J. Earth Sci. 44: 1375-1396. doi:10.1139/E07-040.

Burchfiel, B. C.; Cowan, D. S.; and Davis, G. A. 1992. Tectonic overview of the Cordilleran Orogen in the western U.S. In Burchfiel, B. C.; Lipman, P. W.; and Zoback, M. L., eds. The Cordilleran Orogen: conterminous U.S. (Geology of North America, vol. G-3). Boulder, CO, Geol. Soc. Am., p. 407-480.

Carpenter, P. S., and Walker, N. W. 1992. Origin and tectonic significance of the Aldrich Mountains serpentinite matrix melange, northeastern Oregon. Tectonics 11:690-708. doi:10.1029/91TC03013.

Cawood, P. A.; Hawkesworth, C. J.; and Dhuime, B. 2012. Detrital zircon record and tectonic setting. Geology 40: 875-878. doi:10.1130/G32945.1.

Cecil, M. R.; Rotberg, G.; Ducea, M. N.; Saleeby, J. B.; and Gehrels, G. E. 2012. Magmatic growth and batholithic root development in the northern Sierra Nevada, California. Geosphere 8:1-15. doi:10.1130 /GES00729.1.

Chang, Z.; Vervoort, J. D.; McClelland, W. C.; and Knaack, C. 2006. U-Pb dating of zircon by LA-ICP-MS. Geochem. Geophys. Geosyst. 7:Q05009. doi:10.1029 /2005GC001100

Cloos, M. 1993. Lithospheric buoyancy and collisional orogenesis: subduction of oceanic plateaus, continental margins, island arcs, spreading ridges, and seamounts. Geol. Soc. Am. Bull. 105:715-737.

Coleman, R. G.; Manning, C. E.; Mortimer, N.; Donato, M. M.; and Hill, L. B. 1988. Tectonic and regional metamorphic framework of the Klamath Mountains and adjacent Coast Ranges, California and Oregon. In Ernst, W. G., ed. Metamorphism and crustal evolution of the western United States (Rubey vol. 7). Englewood Cliffs, NJ, Prentice Hall, p. 1059-1097. 
Coney, P. J., and Evenchick, C. A. 1994. Consolidation of the American Cordilleras. J. S. Am. Earth Sci. 7:241262. doi:10.1016/0895-9811(94)90011-6.

Cowan, D. S., and Brandon, M. T. 1981. Contrasting facies in upper Mesozoic strata of Pacific Northwest (abs.). AAPG Bull. 65:913-914. doi:10.1306/2F919D00-16CE -11D7-8645000102C1865D.

Criss, R. E., and Fleck, R. J. 1987. Petrogenesis, geochronology, and hydrothermal systems of the northern Idaho batholith and adjacent areas based on ${ }^{18} \mathrm{O} /{ }^{16} \mathrm{O}, \mathrm{D} /$ $\mathrm{H},{ }^{87} \mathrm{Sr} /{ }^{86} \mathrm{Sr}, \mathrm{K}-\mathrm{Ar}$, and ${ }^{40} \mathrm{Ar} /{ }^{39} \mathrm{Ar}$ studies. In Vallier, T. L., and Brooks, H. C., eds. The Idaho batholith and its border zone. U.S. Geol. Surv. Prof. Pap. 1436:95-137.

Davis, G. A.; Monger, J. W. H.; and Burchfiel, B. C. 1978. Mesozoic construction of the Cordilleran "collage," central British Columbia to central California. In Howell, D. G., and McDougall, K. A., eds. Mesozoic paleogeography of the western United States. Los Angeles, Pacific Section, Pacific Coast Paleogeography Symposium 2.

Day, H. W., and Bickford, M. E. 2004. Tectonic setting of the Jurassic Smartville and Slate Creek complexes, northern Sierra Nevada, California. Geol. Soc. Am. Bull. 116:1515-1528.

Day, H. W.; Moores, E. M.; and Tuminas, A. C. 1985. Structure and tectonics of the northern Sierra Nevada. Geol. Soc. Am. Bull. 96:436-450.

DeCelles, P. G. 2004. Late Jurassic to Eocene evolution of the Cordilleran thrust belt and foreland basin system, western U.S.A. Am. J. Sci. 304:105-168.

DeCelles, P. G.; Ducea, M. N.; Kapp, P.; and Zandt, G. 2009. Cyclicity in Cordilleran orogenic systems. Nat. Geosci. 2:251-257. doi:10.1038/NGEO469.

DeGraaff-Surpless, K.; Graham, S. A.; Wooden, J. L.; and McWilliams, M. O. 2002. Detrital zircon provenance analysis of the Great Valley Group, California: evolution of an arc-forearc system. Geol. Soc. Am. Bull. 114:1564-1580. doi:10.1130/0016-7606(2002)114<1564 :DZPAOT>2.0.CO;2.

Dickinson, W. R. 1979. Mesozoic forearc basin in central Oregon. Geology 7:166-170.

2004. Evolution of the North American Cordillera. Annu. Rev. Earth Planet. Sci. 32:13-45. doi: 10.1146/annurev.earth.32.101802.120257.

. 2006. Geotectonic evolution of the Great Basin. Geosphere 2:353-368. doi:10.1130/GES00054.1.

. 2008. Accretionary Mesozoic-Cenozoic expansion of the Cordilleran continental margin in California and adjacent Oregon. Geosphere 4:329-353. doi:10.1130/GES00105.1.

Dickinson, W. R., and Gehrels, G. E. 2009. Use of U-Pb ages of detrital zircons to infer maximum depositional ages of strata: a test against a Colorado Plateau Mesozoic database. Earth Planet. Sci. Lett. 288:115125.

Dickinson, W. R.; Hopson, C. A.; and Saleeby, J. B. 1996. Alternate origins of the Coast Range ophiolite (California): introduction and implications. GSA Today 6: $1-2$.
Dickinson, W. R., and Lawton, T. F. 2001. Carboniferous to Cretaceous assembly and fragmentation of Mexico. Geol. Soc. Am. Bull. 113:1142-1160.

Dilek, Y. 1989. Tectonic significance of post-accretion rifting of a Mesozoic island-arc terrane in the northern Sierra Nevada, California. J. Geol. 97:503-518.

Dilek, Y.; Moores, E. M.; Erskine, M. C. 1988. Ophiolitic thrust nappes in western Nevada: implications for the Cordilleran Orogen. J. Geol. Soc. 145:969-975.

Dorsey, R. J., and LaMaskin, T. A. 2007. Stratigraphic record of Triassic-Jurassic collisional tectonics in the Blue Mountains province, northeastern Oregon. Am. J. Sci. 307:1167-1193.

- 2008. Mesozoic collision and accretion of oceanic terranes in the Blue Mountains province of northeastern Oregon: new insights from the stratigraphic record. In Spencer, J. E., and Titley, S. R., eds. CircumPacific Tectonics, Geologic Evolution, and Ore deposits. Tucson, AZ, Arizona Geol. Soc. Dig. 22.

Ducea, MN. 2001. The California arc: thick granitic batholiths, eclogitic residues, lithospheric-scale thrusting, and magmatic flare-ups. GSA Today 11:4-10.

Edelman, S. H., and Sharp, W. D. 1989. Terranes, early faults, and pre-Late Jurassic amalgamation of the western Sierra Nevada metamorphic belt, California. Geol. Soc. Am. Bull. 101:1420-1433. doi:10.1130 /0016-7606/1989|101<1420: TEFAPL>2.3.CO;2.

Ernst, W. G. 1990. Accretionary terrane in the Sawyers Bar area of the western Triassic and Paleozoic belt, central Klamath Mountains, northern California. In Harwood, D. S., and Miller, M. M., eds. Paleozoic and early Mesozoic paleogeographic relations: Sierra Nevada, Klamath Mountains, and related terranes. Geol. Soc. Am. Spec. Pap. 255:297-306.

- 2012. Earliest Cretaceous Pacificward offset of the Klamath Mountains salient, NW California-SW Oregon. Lithosphere 5:151-159. doi:10.1130/L247.1. 2015. Review of Late Jurassic-early Miocene sedimentation and plate-tectonic evolution of northern California: illuminating example of an accretionary margin. Chin. J. Geochem. doi:10.1007/s11631 -015-0042-x.

Ernst, W. G.; Saleeby, J. B.; and Snow. C. A. 2009. Guadalupe pluton-Mariposa Formation age relationships in the southern Sierran foothills: onset of Mesozoic subduction in northern California? J. Geophys. Res. 114:B11204. doi:10.1029/2009JB006607.

Ernst, W. G.; Snow, C. A.; and Scherer, H. H. 2008. Mesozoic transpression, transtension, subduction, and metallogenesis in northern and central California. Terra Nova 20:394-413. doi:10.1111/j.1365-3121.2008 .00834.x.

Ferns, M. L., and Brooks, H. C. 1995. The Bourne and Greenhorn subterranes of the Baker terrane, northeastern Oregon: implications for the evolution of the Blue Mountains island-arc system. In Vallier, T. L., and Brooks, H. C., eds. Geology of the Blue Mountains region of Oregon, Idaho and Washington: petrology and tectonic evolution of pre-tertiary rocks of the Blue 
Mountains region. U.S. Geol. Surv. Prof. Pap. 1438: 331-358.

Fleck, R. J., and Criss, R. E. 1985. Strontium and oxygen isotopic variations in Mesozoic and Tertiary plutons of central Idaho. Contrib. Mineral. Petrol. 90:291-308.

Frost, C. D.; Barnes, C. G.; Snoke, A. W. 2006. Nd and Sr isotopic data from argillaceous rocks of the Galice Formation and Rattlesnake Creek terrane, Klamath Mountains: evidence for the input of Precambrian sources. Geol. Soc. Am. Spec. Pap. 410:103-120. doi:10.1130/2006.2410(05).

Garver, J. I. 1988. Fragment of the Coast Range ophiolite and the Great Valley sequence in the San Juan Islands, Washington. Geology 16:948-951. 10.1130/0091-7613 (1988)016<0948:FOTCRO>2.3.CO;2.

Garwood, D. L.; Schmidt, K. L.; Kauffman, J. D.; Stewart, D. E.; Lewis, R.; Othberg, K. L.; and Wampler, P. J. 2008. Geologic map of the White Bird Quadrangle, Idaho County, Idaho. Idaho Geol. Surv., DWM-101, scale $1: 24,000$.

Gaschnig, R. M.; Vervoort, J. D.; Lewis, R. S.; and Tikoff, B. 2011. Isotopic evolution of the Idaho batholith and Challis intrusive province, northern US Cordillera. J. Petrol. 52:2397-2429. doi:10.1093/petrology /egr050.

Getty, S. R.; Selverstone, J.; Wernicke, B. P.; Jacobsen, S. B.; Aliberti, E.; and Lux, D. R. 1993. Sm-Nd dating of multiple garnet growth events in an arc-continent collision zone, northwestern U.S. Cordillera. Contrib. Mineral. Petrol. 115:45-57. doi:10.1007/BF00712977.

Giorgis, S.; McClelland, W.; Fayon, A.; Singer, B. S.; and Tikoff, B. 2008. Timing of deformation and exhumation in the western Idaho shear zone, McCall, Idaho. Geol. Soc. Am. Bull. 120:1119-1133. doi:10.1130 /B26291.1.

Giorgis, S.; Tikoff, B.; and McClelland, W. 2005. Missing Idaho arc: transpressional modification of the ${ }^{87} \mathrm{Sr} /{ }^{86} \mathrm{Sr}$ transition on the western edge of the Idaho batholith. Geology 33:469-472.

Girty, G. H.; Hanson, R. E.; Girty, M. S.; Schweickert, R. A.; Harwood, D. S.; Yoshinobu, A. S.; Bryan, K. A.; Skinner, J. E.; and Hill, C. A. 1995. Timing of emplacement of the Haypress Creek and Emigrant Gap plutons: implications for the timing and controls of Jurassic orogenesis, northern Sierra Nevada, California. In Miller, D. M., and Busby, C., eds. Jurassic magmatism and tectonics of the North American Cordillera. Geol. Soc. Am. Spec. Pap. 299:191-201.

Godfrey, N. J., and Dilek, Y. 2000. Mesozoic assimilation of oceanic crust and island arc into the North American continental margin in California and Nevada: insights from geophysical data. In Dilek, Y., et al., eds. Ophiolites and oceanic crust: new insights from field studies and the Ocean Drilling Program. Geol. Soc. Am. Spec. Pap. 349:365-382.

Goldstrand, P. M. 1994. The Mesozoic geologic evolution of the northern Wallowa terrane, northeastern Oregon and western Idaho. In Vallier, T. L., and Brooks, H. C., eds. Geology of the Blue Mountains region of
Oregon, Idaho, and Washington: stratigraphy, physiography, and mineral resources of the Blue Mountains region. U.S. Geol. Surv. Prof. Pap. 1439:29-53.

Gray, K. D. 2013. Structure of the arc-continent transition in the Riggins region of west-central Idaho-strip maps and structural sections. Idaho Geol. Surv., Technical Report 13-1, 2 plates, scale 1:24,000.

Gray, K. D., and Oldow, J. S. 2005. Contrasting structural histories of the Salmon River belt and Wallowa terrane: implications for terrane accretion in northeastern Oregon and west-central Idaho. Geol. Soc. Am. Bull. 117:687-706.

Gray, K. D.; Watkinson, A. J.; Gaschnig, R. M.; and Isakson, V. H. 2012. Age and structure of the Crevice pluton: overlapping orogens in west-central Idaho? Can. J. Earth Sci. 49:709-731. doi:10.1139/e2012-016.

Hacker, B. R.; Donato, M.; Barnes, C.; McWilliams, M. O.; and Ernst, W. G. 1995. Timescales of orogeny: Jurassic construction of the Klamath Mountains. Tectonics 14:677-703. doi:10.1029/94TC02454.

Hacker, B. R., and Ernst, W. G. 1993. Jurassic orogeny in the Klamath Mountains: a geochronologic perspective. In Mesozoic paleogeography of the western United States-II. Los Angeles, Pac. Sect. Soc. Econ. Paleontol. Mineral., vol. 71, p. 31-60.

Hacker, B. R.; Ernst, W. G.; and McWilliams, M. O. 1993. Genesis and evolution of a Permian-Jurassic magmatic arc/accretionary wedge, and reevaluation of terranes in the central Klamath Mountains. Tectonics 12: 387-409. doi:10.1029/92TC02250.

Harper, G. D. 1980. The Josephine ophiolite-remains of a Late Jurassic marginal basin in northwestern California. Geology 8:333-337. doi:10.1130/0091-7613(1980) 8<333:TJOOAL $>2.0 . C O ; 2$.

Harper, G. D.; Miller, R. B.; MacDonald, J. H., Jr.; Miller, J. S.; and Mlinarevic, A. N. 2003. Evolution of a polygenetic ophiolite: the Jurassic Ingalls ophiolite, Washington Cascades. In Swanson, T. W., ed., Western Cordillera and adjacent areas. Boulder, CO, Geol. Soc. Am. Field Guide 4, p. 251-265.

Harper, G. D.; Saleeby, J. B.; and Heizler, M. 1994. Formation and emplacement of the Josephine ophiolite and the Nevadan orogeny in the Klamath Mountains, California-Oregon: $\mathrm{U} / \mathrm{Pb}$ zircon and ${ }^{40} \mathrm{Ar} /{ }^{39} \mathrm{Ar}$ geochronology. J. Geophys. Res. 99:4293-4321. doi:10.1029 /93JB02061.

Harper, G. D., and Wright, J. E. 1984. Middle to Late Jurassic tectonic evolution of the Klamath Mountains, California-Oregon. Tectonics 3:759-772. doi:10.1029 /TC003i007p00759.

Herzig, C. T., and Sharp, W. D. 1992. The Sullivan Creek terrane: a composite Jurassic arc assemblage, western Sierra Nevada metamorphic belt, California. Geol. Soc. Am. Bull. 104:1292-1300. doi:10.1130/0016-7606 (1992)104<1292:TSCTAC>2.3.CO;2.

Hildebrand, R. S. 2009. Did westward subduction cause Cretaceous-Tertiary orogeny in the North American Cordillera? Geol. Soc. Am. Spec. Pap. 457, 71 p. doi: 10.1130/2009.2457. 
- 2013. Mesozoic assembly of the North American Cordillera. Geol. Soc. Am. Spec. Pap. 495, 169 p.

Housen, B. A., and Dorsey, R. J. 2005. Paleomagnetism and tectonic significance of Albian and Cenomanian turbidites, Ochoco Basin, Mitchell Inlier, central Oregon. J. Geophys. Res. 110:B07102. doi:10.1029 /2004JB003458.

Imlay, R. W. 1964. Middle Jurassic (Bajocian) ammonites from the Cook Inlet region, Alaska. U.S. Geol. Survey Prof. Pap. 418-B:1-61.

. 1980. Jurassic paleobiogeography of the conterminous United States in its continental setting. U.S. Geol. Surv. Prof. Pap. 1062:1-134.

- 1981. Jurassic (Bathonian and Callovian) ammonites in eastern Oregon and western Idaho. U.S. Geol. Survey Prof. Pap. 1142, 42 p.

1986. Jurassic ammonites and biostratigraphy of eastern Oregon and western Idaho. In Vallier, T. L., and Brooks, H. C., eds. Geology of the Blue Mountains region of Oregon, Idaho, and Washington: geologic implications of Paleozoic and Mesozoic paleontology and biostratigraphy, Blue Mountains province, Oregon and Idaho. U.S. Geol. Surv. Prof. Pap. 1435:5357.

Ingersoll, R. V. 1983. Petrofacies and provenance of late Mesozoic forearc basin, northern and central California. AAPG Bull. 67:1125-1142.

Ingersoll, R. V., and Schweickert, R. A. 1986. A platetectonic model for Late Jurassic ophiolite genesis, Nevadan orogeny and forearc initiation, northern California. Tectonics 5:901-912.

Irwin, W. P. 2003. Correlation of the Klamath Mountains and Sierra Nevada. Sheet 1: Map showing accreted terranes and plutons of the Klamath Mountains and Sierra Nevada, scale 1:1,000,000. Sheet 2: Successive accretionary episodes of the Klamath Mountains and northern part of the Sierra Nevada. U.S. Geol. Surv. Open-File Rep. 02-490, 2 sheets.

Irwin, W. P., and Wooden, J. L. 2001. Maps showing plutons and accreted terranes of the Sierra Nevada, California, with a tabulation of $\mathrm{U} / \mathrm{Pb}$ isotopic ages. U.S. Geol. Surv. Open-File Rep. 01-299, scale 1:100,000.

Jaffey, A. H.; Flynn, K. F.; Glendenin, L. E.; Bentley, W. C.; and Essling, A. M. 1971. Precision measurement of the half-lives and specific activities of U235 and U238. Phys. Rev. C4:1889-1907.

Jordan, T. E. 1981. Thrust loads and foreland basin evolution, Cretaceous, western United States. AAPG Bull. 65:2506-2520.

Kauffman, J. D.; Garwood, D. L.; Schmidt, K. L.; Lewis, R. S.; Othberg, K. L.; and Phillips, W. M. 2009. Geologic map of the Idaho part of the Orofino and Clarkston $30 \times 60$ minute quadrandles. Idaho Geol. Surv., Geologic Map 48, scale 1:100,000.

Kays, M. A.; Stimac, J. P.; and Goebel, P. M. 2006. Permian-Jurassic growth and amalgamation of the Wallowa composite terrane, northeastern Oregon. In Snoke, A. W., and Barnes, C. A., eds. Geological studies in the Klamath Mountains province, California and
Oregon-a volume in honor of William P. Irwin. Geol. Soc. Am. Spec. Pap. 410:465-494.

Klemetti, E. W.; Lackey, J. S.; and Starnes, J. 2013. Magmatic lulls in the Sierra Nevada captured in zircon from rhyolite of the Mineral King pendant, California. Geosphere 10:66-79. doi:10.1130/GES00920.1.

Kurz, G. A. 2010. Geochemical, isotopic, and U-Pb geochronologic investigations of intrusive basement rocks from the Wallowa and Olds Ferry arc terranes, Blue Mountains province, Oregon-Idaho. PhD dissertation, Boise State University, Boise, Idaho.

Kurz, G. A.; Schmitz, M. D.; Northrup, C. J.; and Vallier, T. L. 2011. U-Pb geochronology and geochemistry of intrusive rocks from the Cougar Creek Complex, Wallowa arc terrane, Blue Mountains province, OregonIdaho. Geol. Soc. Am. Bull. 124:578-595. doi:10.1130 /B30452.1.

LaMaskin, T. A. 2012. Detrital zircon facies of Cordilleran terranes in western North America. GSA Today 22:4-11. doi:10.1130/GSATG142A.1.

LaMaskin, T. A.; Dorsey, R. J.; and Vervoort, J. V. 2008 a. Tectonic controls on mudrock geochemistry, Mesozoic rocks of eastern Oregon and western Idaho, U.S.A.: implications for Cordilleran tectonics. J. Sediment. Res. 78:765-783. doi:10.2110/jsr.2008.087.

LaMaskin, T. A.; Schwartz, J. J.; Dorsey, R. J.; Snoke, A. W.; Johnson, K.; and Vervoort, J. D. 2009. Mesozoic sedimentation, magmatism, and tectonics in the Blue Mountains province, northeastern Oregon. In O'Connor, J. E.; Dorsey, R. J.; and Madin, I. P., eds. Volcanoes to vineyards: geologic field trips through the dynamic landscape of the Pacific Northwest. Geol. Soc. Am. Field Guide 15. doi:10.1130/2009.fld015(09).

LaMaskin, T. A.; Stanley, G. D., Jr.; Caruthers, A.; and Rosenblatt, M. 2011a. Detrital record of Upper Triassic reef facies in the Blue Mountains province, northeastern Oregon: implications for early Mesozoic paleogeography of western North American Cordilleran terranes. PALAIOS 26:779-789. doi:10.2110/palo.2011 .p11-006r.

LaMaskin, T. A.; Vervoort, J. D.; and Dorsey, R. J. 2008 b. Geochemical, isotopic and detrital-zircon provenance of Mesozoic rocks, Oregon and Idaho, U.S.A. (abstr.): Goldschmidt 2008, Vancouver, B.C. Geochim. et Cosmochem. 72:A513.

- 2011b. Early Mesozoic paleogeography and tectonic evolution of the western United States: insights from detrital zircon U-Pb geochronology of the Blue Mountains province, northeastern Oregon, U.S.A. Geol. Soc. Am. Bull. 123:1939-1965. doi:10.1130 /B30260.1.

Ludwig, K. R. 2003. User's manual for Isoplot/Ex, version 3.0: a geochronological toolkit for Microsoft Excel. Berkeley Geochronol. Cent. Spec. Pub. vol. 4.

Lund, K.; Aleinekoff, J. N.; and Dee, S. M. 2007. Shrimp $\mathrm{U}-\mathrm{Pb}$ constraints on age and provenance of the Riggins Group and associated metamorphic rocks west of the Salmon River suture, west-central Idaho: tectonic implications. Geol. Soc. Am. Abstr. Program 39:289. 
Lund, K., and Snee, L. W. 1988. Metamorphism, structural development, and age of the continent-island arc juncture in west-central Idaho. In Ernst, W. G., ed. Metamorphism and crustal evolution of the western United States (Rubey vol. 3). Englewood Cliffs, NJ, Prentice Hall, p. 297-331.

MacDonald, J. H., Jr.; Harper, G. D.; and Zhu, B. 2006. Petrology, geochemistry, and provenance of the Galice Formation, Klamath Mountains, Oregon and California. In Snoke, A. W., and Barnes, C. G., eds. Geological studies in the Klamath Mountains province, California and Oregon: a volume in honor of William P. Irwin. Geol. Soc. Am. Spec. Pap. 410:77-101. doi:10.1130/2006 .2410(04).

Mattinson, J. M. 2005. Zircon U-Pb chemical abrasion ("CA-TIMS") method: combined annealing and multistep partial dissolution analysis for improved precision and accuracy of zircon ages. Chem. Geol. 220:47-66.

McClelland, W. C.; Gehrels, G. E.; and Saleeby, J. B. 1992. Upper Jurassic-lower Cretaceous basinal strata along the Cordilleran margin: implications for the accretionary history of the Alexander-Wrangellia-Peninsular terrane. Tectonics 11:832-835.

McClelland, W. C.; Tikoff, B.; and Manduca, C. A. 2000. Two-phase evolution of accretionary margins: examples from the North American Cordillera. Tectonophysics 326:37-55. doi:10.1016/S0040-1951(00)00145 -1 .

McRoberts, C. A. 1993. Systematics and biostratigraphy of halobiid bivalves from the Martin Bridge Formation (Upper Triassic), northeast Oregon. J. Paleontol. 67: 198-210.

Metzger, E. P.; Miller, R. B.; and Harper, G. D. 2002. Geochemistry and tectonic setting of the ophiolitic Ingalls Complex, North Cascades, Washington: implications for correlations of Jurassic Cordilleran ophiolites. J. Geol. 110:543-560.

Miller, J. S.; Miller, R. B.; Wooden, J. L.; and Harper, G. D. 2003. Geochronologic links between the Ingalls ophiolite, North Cascades, Washington and the Josephine ophiolite, Klamath Mts., Oregon and California. Geol. Soc. Am. Abstr. Program 35:113.

Miller, M. M., and J. B. Saleeby. 1995. U-Pb geochronology of detrital zircon from Upper Jurassic synorogenic turbidites, Galice Formation, and related rocks, western Klamath Mountains: correlation and Klamath Mountains provenance. J. Geophys. Res. 100:18,04518,058. doi:10.1029/95JB00761.

Monger, J. W. H., and Price, R. A. 1979. Geodynamic evolution of the Canadian cordillera-progress and problems. Can. J. Earth Sci. 16:770-791.

Moores, E. 1970. Ultramafics and orogeny, with models of the US Cordillera and the Tethys. Nature 228:837842. doi:10.1038/228837a0.

Moores, E. M.; Wakabayashi, J.; and Unruh, J. R. 2002. Crustal-scale cross-section of the U.S. Cordillera, California and beyond, its tectonic significance, and speculations on the Andean orogeny. Int. Geol. Rev. 44: 479-500.
Morrison, R. K. 1963. Pre-Tertiary geology of the Snake River Canyon between Cache Creek and Dug Bar, Oregon-Idaho boundary. PhD dissertation, University of Oregon, Eugene.

Nolf, B. 1966. Geology and stratigraphy of part of the northern Wallowa Mountains, Oregon. PhD dissertation: Princeton University, Princeton, NJ.

Norman, E. A. S. 1984. The structure and petrology of the Summit Valley area, Klamath Mountains, California. MS thesis, University of Utah, Salt Lake City.

Northrup, C. J.; Schmitz, M.; Kurz, G.; and Tumpane, K. 2011. Tectonomagmatic evolution of distinct arc terranes in the Blue Mountains province, Oregon and Idaho. In Lee, J., and Evans, J. P., eds. Geologic field trips to the basin and range, Rocky Mountains, Snake River Plain, and terranes of the U.S. Cordillera. Geol. Soc. Am. Field Guide 21:67-88.

Oldow, J. S. 1984. Evolution of a late Mesozoic back-arc fold and thrust belt, northwestern Great Basin, USA. Tectonophysics 102:245-274.

Oldow, J. S.; Bally, A. W.; Avé Lallemant, H. G.; and Leeman, W. P. 1989. Phanerozoic evolution of the North American Cordillera: United States and Canada (Geology of North America, vol. A). Boulder, CO, Geol. Soc. Am., p. 139-232.

Payne, J. D., and Northrup, C. J. 2003. Geologic map of the Monroe Butte 7.5-Minute Quadrangle, Washington County, Idaho, and Baker County, Oregon. Idaho Geol. Surv. Tech. Rep. T-03-01, scale: 1:24,000.

Pessagno, E. A., Jr. 2006. Faunal evidence for the tectonic transport of Jurassic terranes in Oregon, California, and Mexico. Geol. Soc. Am. Spec. Pap. 410:31-52. doi: 10.1130/2006.2410(02).

Pessagno, E. A., Jr., and Blome, C. D. 1986. Faunal affinities and tectonogenesis of Mesozoic rocks in the Blue Mountains province of eastern Oregon and western Idaho. In Vallier, T. L., and Brooks, H. C., eds. Geologic implications of Paleozoic and Mesozoic paleontology and biostratigraphy, Blue Mountains province, Oregon and Idaho. U.S. Geol. Surv. Prof. Pap. 1435:6578.

Saleeby, J. B. 1982. Polygenetic ophiolite belt of the California Sierra Nevada: geochronological and tectonostratigraphic development. J. Geophys. Res. 87: 1803-1824. doi:10.1029/JB087iB03.

Saleeby, J. B., and Busby-Spera, C. 1992. Early Mesozoic tectonic evolution of the western U.S. Cordillera. In Burchfiel, B. C.; Lipman, P. W.; and Zoback, M. L., eds. The Cordilleran Orogen: conterminous U.S. (Geology of North America, vol. G-3). Boulder, CO, Geol. Soc. Am., p. 107-168.

Saleeby, J. B.; Harper, G. D.; Snoke, A. W.; and Sharp, W. D. 1982. Time relations and structural-stratigraphic patterns in ophiolite accretion, west central Klamath Mountains, California. J. Geophys. Res. 87:3831-3848.

Sambridge, M. S., and Compston, W. 1994. Mixture modeling of multi-component data sets with application to ion-probe zircon ages. Earth Planet. Sci. Lett. 128:373-390. 
Schmidt, K. L.; Kauffman, J. D.; Stewart, D. E.; Garwood, D. L.; Othberg, K. L.; and Lewis, R. S. 2009. Geologic map of the Grave Point Quadrangle, Idaho County, Idaho, and Wallowa County, Oregon. Idaho Geol. Sur., Digital Web Map 111, scale 1:24,000.

Schmidt, K. L.; Schwartz, D. M.; Lewis, R. S.; Vervoort, J. D.; LaMaskin, T. A.; and Wilford, D. E. 2013. New detrital zircon ages constrain the origin and evolution of the Riggins Group assemblage along the Salmon River Suture Zone, western Idaho (abstr.). Geol. Soc. Am. Abstr. Program 45:66.

Schmitz, M. D. 2012. Radiogenic isotope geochronology. In Gradstein, F. M.; Ogg, J. G.; Schmitz, M. D.; and Ogg, G. M., eds. The geologic timescale 2012. Amsterdam, Elsevier. doi:10.1016/B978-0-444-59425-9.02001-1.

Schmitz, M. D., and Schoene, B. 2007. Derivation of isotope ratios, errors, and error correlations for $\mathrm{U}-\mathrm{Pb}$ geochronology using $\left.{ }^{205} \mathrm{~Pb}-{ }^{235} \mathrm{U}-{ }^{233} \mathrm{U}\right)$-spiked isotope dilution thermal ionization mass spectrometric data. Geochem. Geophys. Geosyst. 8:Q08006. doi:10.1029 /2006GC001492.

Schwartz, J. J.; Johnson, K.; Miranda, E. A.; and Wooden, J. L. 2011a. The generation of high Sr/Y plutons following Late Jurassic arc-arc collision, Blue Mountains province, NE Oregon. Lithos 126:22-41. doi:10.1016 /j.lithos.2011.05.005.

Schwartz, J. J.; Johnson, K.; Mueller, P.; Valley, J.; Strickland, A.; and Wooden, J. 2014. Time scales and processes of Cordilleran batholith construction and high-Sr/Y magmatic pulses: evidence from the Bald Mountain batholith, northeastern Oregon. Geosphere 10. doi:10.1130/GES01033.1.

Schwartz, J. J.; Snoke, A. W.; Cordey, F.; Johnson, K.; Frost, C. D.; Barnes, C. G.; LaMaskin, T. A.; and Wooden, J. L. 2011b. Late Jurassic magmatism, metamorphism and deformation in the Blue Mountains province, northeast Oregon. Geol. Soc. Am. Bull. 123: 2083-2111. doi:10.1130/B30327.1

Schwartz, J. J.; Snoke, A. W.; Frost, C. D.; Barnes, C. G.; Gromet, L. P.; and Johnson, K. 2010. Analysis of the Wallowa-Baker terrane boundary: implications for tectonic accretion in the Blue Mountains province, northeastern Oregon. Geol. Soc. Am. Bull. 122:517-536. doi:10.1130/B26493.1.

Schweickert, R. A.; Bogen, N. L.; Girty, G. H.; Hanson, R. E.; and Merguerian, C. 1984. Timing and structural expression of the Nevadan orogeny, Sierra Nevada, California. Geol. Soc. Am. Bull. 95:967-979.

Schweickert, R. A., and Cowan, D. S. 1975. Early Mesozoic tectonic evolution of the western Sierra Nevada, California. Geol. Soc. Am. Bull. 86:1329-1336. doi: 10.1130/0016-7606(1975)86<1329:EMTEOT>2.0.CO;2.

Schweickert, R. A.; Hanson, R. E.; and Girty, G. H. 1999. Accretionary tectonics of the western Sierra Nevada metamorphic belt. In Wagner, D. L., and Graham, S. A., eds. Geologic field trips in northern California. Calif. Div. Mines Geol. Spec. Pub. 119:33-79.

Selverstone, J.; Wernicke, B. P.; and Aliberti, E. A. 1992. Intracontinental subduction and hinged unroofing along the Salmon River suture zone, west central Idaho. Tectonics 11:124-144.

Sharp, W. D. 1988. Pre-Cretaceous crustal evolution in the Sierra Nevada region, California. In Ernst, W. G., ed. Metamorphism and crustal evolution of the western United States (Rubey vol. 7). Englewood Cliffs, NJ, Prentice-Hall, p. 823-864.

Shervais, J. W.; Murchey, B. L.; Kimbrough, D. L.; Renne, P. R.; and Hanan, B. 2005. Radioisotopic and biostratigraphic age relations in the Coast Range ophiolite, northern California: implications for the tectonic evolution of the western Cordillera. Geol. Soc. Am. Bull. 117:633-653. doi:10.1130/B25443.1.

Sigloch, K., and Mihalynuk, M. G. 2013. Intra-oceanic subduction shaped the assembly of Cordilleran North America. Nature 496:50-56. doi:10.1038/nature12019.

Smith, P. L. 1980. Correlation of the members of the Jurassic Snowshoe Formation in the Izee basin of eastcentral Oregon. Can. J. Earth Sci. 17:1603-1608. doi: 10.1139/e80-171.

Snee, L. W.; Davidson, G. F.; and Unruh, D. M. 2007. Geologic, geochemical and ${ }^{40} \mathrm{Ar} /{ }^{39} \mathrm{Ar}$ and $\mathrm{U}-\mathrm{Pb}$ thermochronologic constraints for the tectonic development of the Salmon River suture zone near Orofino, Idaho. In Kuntz, M. A., and Snee, L. W. eds. Geologic studies of the Salmon River suture zone and adjoining areas, west-central Idaho and eastern Oregon. U.S. Geol. Surv. Prof. Pap. 1738:51-94.

Snee, L. W.; Lund, K.; Sutter, J. F.; Balcer, D. E.; and Evans, K. V. 1995. An ${ }^{40} \mathrm{Ar} /{ }^{39} \mathrm{Ar}$ chronicle of the tectonic development of the Salmon River suture zone, western Idaho. In Vallier, T. L., and Brooks, H. C., eds. Geology of the Blue Mountains region of Oregon, Idaho, and Washington: petrology and tectonic evolution of preTertiary rocks of the Blue Mountains region. U.S. Geol. Surv. Prof. Pap. 1438:359-414.

Snoke, A. W. 1977. A thrust plate of ophiolitic rocks in the Preston Peak area, Klamath Mountains, California. Geol. Soc. Am. Bull. 88:1641-1659. doi:10.1130 /0016-7606(1977)88<1641:ATPOOR>2.0.CO;2.

Snow, C. A. 2007. Petrotectonic evolution and melt modeling of the Peñon Blanco arc, central Sierra Nevada foothills, California. Geol. Soc. Am. Bull. 119:10141024. doi:10.1130/B25972.1.

Snow, C. A., and W. G. Ernst. 2008. Detrital zircon constraints on sediment distribution and provenance of the Mariposa Formation, central Sierra Nevada foothills, California. In Wright, J. E., and Shervais, J. W., eds. Ophiolites, arcs, and batholiths: a tribute to Cliff Hopson. Geol. Soc. Am. Spec. Pap. 438:311-330.

Snow, C. A., and Scherer, H. H. 2006. Terranes of the western Sierra Nevada foothills metamorphic belt, California: a critical review. Int. Geol. Rev. 48:46-62. doi:10.2747/0020-6814.48.1.46.

Stanley, G. D., Jr., and Beauvais, L. 1990. Middle Jurassic corals from the Wallowa terrane, west-central Idaho. J. Paleontol. 64:352-362.

Surpless, K. D.; Graham, S. A.; Covault, J. A.; and Wooden, J. L. 2006. Does the Great Valley Group 
contain Jurassic strata? reevaluation of the age and early evolution of a classic forearc basin. Geology 34: 21-24. doi:10.1130/G21940.1.

Tobisch, O. T.; Paterson, S. R.; Saleeby, J. B.; and Geary, E. E. 1989. Nature and timing of deformation in the foothills terrane, central Sierra Nevada, California: its bearing on onorogenesis. Geol. Soc. Am. Bull. 101: 401-413.

Traverse, A. T., and Ash, S. R. 1994. Well-preserved fungal spores from the Jurassic rocks of Hells Canyon on the Idaho- Oregon border. J. Paleontol. 68:664-668.

Tumpane, K. P. 2010. Age and isotopic investigations of the Olds Ferry terrane and its relations to other terranes of the Blue Mountains province, eastern Oregon and west-central Idaho. MS thesis, Boise State University, Boise, Idaho.

Unruh, D. M.; Lund, K.; Kuntz, M. A.; and Snee, L. W. 2008. Uranium-lead zircon ages and $\mathrm{Sr}, \mathrm{Nd}$, and $\mathrm{Pb}$ isotope geochemistry of selected plutonic rocks from western Idaho. U.S. Geol. Surv. Open-File Rep. 2008$1142,37 \mathrm{p}$.

Vallier, T. L. 1977. The Permian and Triassic Seven Devils Group, western Idaho and northeast Oregon. U.S. Geol. Surv. Bull. 1437, 58 p.

1995. Petrology of pre-Tertiary igneous rocks in the Blue Mountains region of Oregon, Idaho, and Washington: implications for the geologic evolution of a complex island arc. In Vallier, T. L., and Brooks, H. C., eds. Geology of the Blue Mountains region of Oregon, Idaho, and Washington: petrology and tectonic evolution of pre-Tertiary rocks of the Blue Mountains region. U.S. Geol. Surv. Prof. Pap. 1438: 125-209.

_ 1998. Islands and rapids: a geologic story of Hells Canyon. Lewiston, ID, Confluence Press, Lewis-Clark State College, $151 \mathrm{p}$.

Vervoort, J. D., and Blichert-Toft, J. 1999. Evolution of the depleted mantle: Hf isotope evidence from juvenile rocks through time. Geochim. Cosmochim. Acta 63:533-556.

Walker, N. W. 1995. Tectonic implications of U-Pb zircon ages of the Canyon Mountain complex, Sparta complex, and related metaplutonic rocks of the Baker terrane, northeastern Oregon. In Vallier, T. L., and Brooks, H. C., eds. Geology of the Blue Mountains region of Oregon, Idaho, and Washington: petrology and tectonic evolution of pre-Tertiary rocks of the Blue Mountains region. U.S. Geol. Surv. Prof. Pap. 1438: 247-269.

White, D. L., and Vallier, T. L. 1994. Geologic evolution of the Pittsburg Landing area, Snake River Canyon, Oregon and Idaho. In Vallier, T. L., and Brooks, H. C., eds. Stratigraphy, physiography, and mineral resources of the Blue Mountains region. U.S. Geol. Surv. Prof. Pap. 1439:55-74.

White, J. D. L. 1986. The Doyle Creek Formation (Seven Devils Group), Pittsburg Landing, Idaho: a study of intraarc sedimentation. MS thesis, University of Missouri, Columbia.
- 1994. Intra-arc basin deposits within the Wallowa terrane, Pittsburg Landing area, Oregon and Idaho. In Vallier, T. L., and Brooks, H. C., ed. Stratigraphy, physiography, and mineral resources of the Blue Mountains region. U.S. Geol. Surv. Prof. Pap. 1439:7590.

White, J. D. L.; White, D. L.; Vallier, T. L.; Stanley, G. D., Jr.; and Ash, S. R. 1992. Middle Jurassic strata link Wallowa, Olds Ferry, and Izee terranes in the accreted Blue Mountains island arc, northeastern Oregon. Geology 20:729-732.

Wright, J. E., and Fahan, M. R. 1988. An expanded view of Jurassic orogenesis in the western United States Cordillera: Middle Jurassic (pre-Nevadan) regional metamorphism and thrust faulting within an active arc environment, Klamath Mountains, California. Geol. Soc. Am. Bull. 100:859-876.

Wright, J. E., and Wyld, S. J. 1986. Significance of xenocrystic Precambrian zircon contained within the southern continuation of the Josephine ophiolite: Devils Elbow ophiolite remnant, Klamath Mountains, northern California. Geology 14:671-674. doi:10.1130 /0091-7613(1986)14<671:SOXPZC>2.0.CO;2.

- 1994. The Rattlesnake Creek terrane, Klamath Mountains, California: an early Mesozoic volcanic arc and its basement of tectonically disrupted oceanic crust. Geol. Soc. Am. Bull. 106:1033-1056. doi:10.1130/0016 -7606(1994)106<1033:TRCTKM>2.3.CO;2.

- 2006. Gondwanan, Iapetan, Cordilleran interactions: a geodynamic model for the Paleozoic tectonic evolution of the North American Cordillera. In Haggart, J. E.; Enkin, R. J.; and Monger, J. W. H., eds. Paleogeography of the North American Cordillera: evidence for and against large-scale displacements. Geol. Assoc. Can. Spec. Pap. 46:377-408.

Wyld, S. J. 1985. Geology of the western Jurassic Belt, South Fork Trinity River area, Klamath Mountains, California. MS thesis, University of California, Berkeley. . 2002. Structural evolution of a Mesozoic backarc fold-and-thrust belt in the U.S. Cordillera: new evidence from northern Nevada. Geol. Soc. Am. Bull. 114:1452-1468. doi:10.1130/0016-7606(2002)114<1452: SEOAMB $>2.0 . \mathrm{CO} ; 2$.

Wyld, S. J.; Rogers, J. W.; and Copeland, P. 2003. Metamorphic evolution of the Luning-Fencemaker FoldThrust Belt, Nevada: illite crystallinity, metamorphic petrology, and ${ }^{40} \mathrm{Ar} /{ }^{39} \mathrm{Ar}$ geochronology. J. Geol. 111: 17-38.

Wyld, S. J.; Umhoefer, P. J.; and Wright, J. E. 2006. Reconstructing northern Cordilleran terranes along known Cretaceous and Cenozoic strike-slip faults: implications for the Baja British Columbia hypothesis and other models. In Haggart, J. W.; Enkin, R. J.; and Monger, J. W. H., eds. Paleogeography of the North American Cordillera: evidence for and against largescale displacements. Geol. Assoc. Can. Spec. Pap. 46: 277-298.

Wyld, S. J., and Wright, J. E. 1988. The Devils Elbow ophiolite remnant and overlying Galice Formation: 
new constraints on the Middle to Late Jurassic evolution of the Klamath Mountains, California. Geol. Soc. Am. Bull. 100:29-44. doi:10.1130/0016-7606/1988)100 $<0029$ :TDEORA $>2.3 . \mathrm{CO} ; 2$.

. 2001. New evidence for Cretaceous strike-slip faulting in the United States Cordillera and implications for terrane-displacement, deformation patterns, and plutonism. Am. J. Sci. 301:150-181.

. 2005. Early Cretaceous, margin-parallel, dextral faulting and terrane translation in the U.S. Cordillera (abstr.). Geol. Soc. Am. Abstr. Program 37:102.

Yule, J. D.; Saleeby, J. B.; and Barnes, C. G. 2006. A rift-edge facies of the Late Jurassic Rogue-Chetco arc and Josephine ophiolite, Klamath Mountains, Oregon. Geol.
Soc. Am. Spec. Pap. 410:53-76. doi:10.1130/2006.2410 (03).

Yule, J. D.; Wiley, T.; Kays, M. A.; and Murray, R. 2009. Late Triassic to Late Jurassic petrotectonic history of the Oregon Klamath Mountains. In O'Connor, J. E.; Dorsey, R. J.; and Madin, I. P., eds. Volcanoes to vineyards: geologic field trips through the dynamic landscape of the Pacific Northwest. Geol. Soc. Am. Field Guide 15:165-185. doi:10.1130/2009.fld015(08).

Žák, J.; Verner, K.; Johnson, K.; and Schwartz, J. J. 2012. Magnetic fabric of Late Jurassic arc plutons and kinematics of terrane accretion in the Blue Mountains, northeastern Oregon. Gondwana Res. 22:341-352. doi:10.1016/j.gr.2011.09.013. 